\title{
COVID-19 - obraz neurologiczny w populacji pediatrycznej
}

\author{
COVID-19 - the neurological picture in the pediatric population
}

\author{
Julianna Szwancyber* (D), Natalia Symela* (D), Anna Szwinge*(iD), Justyna Paprocka ** (D) \\ *Studenckie Towarzystwo Naukowe przy Katedrze i Klinice Neurologii Dziecięcej, Wydział Nauk Medycznych w Katowicach, \\ Śląski Uniwersytet Medyczny, Katowice \\ **Katedra i Klinika Neurologii Dziecięcej, Wydział Nauk Medycznych w Katowicach, Śląski Uniwersytet Medyczny, Katowice \\ DOI:10.20966/chn.2020.59.465
}

\section{STRESZCZENIE}

SARS-CoV-2 (severe acute respiratory syndrome coronavirus 2) wywołujący COVID-19 (corona virus disease 2019) rozprzestrzenił się po świecie w błyskawicznym tempie, prowadząc do ogłoszenia przez Światową Organizację Zdrowia (World Health Organization, WHO) stanu pandemii. COVID-19 najczęściej kojarzony jest z objawami ze strony układu oddechowego. Dotychczasowe doniesienia w piśmiennictwie z zakresu nauk medycznych informują również o występowaniu objawów pochodzących z innych układów m.in. sercowo-naczyniowego, pokarmowego oraz nerwowego. Objawy neurologiczne powszechnie kojarzone z COVID-19 to ból głowy oraz utrata węchu i smaku. Nie są to jednak jedyne symptomy ze strony układu nerwowego, które mogą wystąpić w przebiegu COVID-19. Choć najbardziej narażone na zachorowanie są osoby starsze, obciążone chorobami przewlekłymi, to wirus dotyka również dzieci. Większość z nich przechodzi zakażenie łagodnie lub bezobjawowo. Zdarzają się jednak przypadki, gdy w przebiegu choroby występują objawy neurologiczne, nierzadko prowadzące do stanu zagrożenia życia. Celem pracy jest podsumowanie informacji na temat dotychczas opublikowanych objawów neurologicznych COVID-19 w populacji pediatrycznej, ocena możliwych patomechanizmów ich powstawania oraz porównanie z objawami występującymi u dorosłych.

Słowa kluczowe: COVID-19, SARS-CoV-2, objawy neurologiczne

\section{ABSTRACT}

The SARS-CoV-2 causing COVID-19 has spread around the world at a rapid pace leading the WHO to declare a pandemic. COVID-19 is most often associated with respiratory symptoms. Unfortunately, on the basis of previous reports, symptoms from other systems were also observed including cardiovascular, digestive and nervous. Neurological symptoms commonly associated with COVID-19 are headache and loss of smell and taste. However, these are not the only symptoms from the nervous system that may occur in the course of COVID-19. Although the elderly with chronic diseases are most at risk, the virus also affects children. Most of them are infected mildly or asymptomatically. However, there are cases when neurological symptoms occur in the course of the disease, not infrequently leading to a life-threatening condition. The aim of the study is to summarize the information on the previously described neurological symptoms of COVID-19 in the pediatric population, to evaluate possible pathomechanisms of their formation and to compare them with the symptoms occurring in adults.

Key words: COVID-19, SARS-CoV-2, neurological symptoms, children

\section{WSTĘP}

Pandemia COVID-19 spowodowała ogromne zmiany w życiu ludzi na całym świecie. Przestrzeganie zaleceń sanitarnych i stosowanie się do obowiązujących restrykcji stało się codziennością, mającą uchronić przed zachorowaniem. Pierwsze przypadki zapalenia płuc o nieznanej etiologii odnotowano pod koniec 2019 roku w Chinach. Na początku roku 2020 za czynnik etiologiczny uznano SARS-CoV-2. Wirus ten należy do rodziny koronawirusów i zawiera jednoniciowe RNA o dodatniej polarności [1]. Przenoszony jest drogą kropelkową i kontaktową, a jego obecność potwierdzono między innymi w wydzielinie z nosa i gardła, w stolcu, moczu i krwi [2, 3]. Do komórki gospodarza SARS-CoV-2 dostaje się poprzez endocytozę, która możliwa jest dzięki obecności białek strukturalnych na powierzchni wirusa. Szczególną rolę w tym procesie odgrywa białko fuzyjne S (ang. spike), które odpowiada za interakcję z receptorem na powierzchni komórki docelowej [1]. SARS-CoV-2 wywołuje ostrą chorobę układu oddechowego, określaną jako COVID-19. Powszechnie wiadomo, że jest ona szczególnie groźna dla osób starszych, cierpiących z powodu chorób współistniejących. Nie oznacza to jednak, że wirus nie jest realnym zagrożeniem dla osób młodych i dzieci. Według raportu „Children and COVID-19: State- Level Data Report" opublikowanego 10.12.2020r. przez American Academy of Pediatrics, $12,2 \%(1,639,728 / 13,462,337)$ odnotowanych zakażeń pojawiło się u dzieci, z których 0,2\%-4,4\% zakażonych wymagało hospitalizacji. Dane dostępne w raporcie wskazują, że $0,00 \%-0,10 \%$ zakażeń u dzieci skutkowało zgonem.

Choroba może mieć bardzo zróżnicowany przebieg - od całkowicie bezobjawowego po kończący się niewydolnością oddechową, ciężki przebieg, wymagający zapewnienia pacjentowi wentylacji mechanicznej. Ryzyko ciężkiego przebiegu COVID-19 wzrasta wraz z wiekiem pacjenta. Pozostałymi czynnikami predysponującymi do ciężkiego przebiegu COVID-19 są: wysokie stężenie białka C-reaktywnego (CRP) oraz D-dimerów, wysoka punktacja w skali SOFA (ang. sequential organ failure assessment score, 
skala niewydolności narządów związana z sepsą), wysoka temperatura ciała, obniżone stężenie albumin we krwi oraz rozpoznana cukrzyca [4]. Wśród schorzeń, które najczęściej współistniały z niekorzystnym przebiegiem COVID-19 znalazły się również nadciśnienie tętnicze i inne choroby układu krążenia oraz choroby układu oddechowego [5]. Nie bez znaczenia pozostaje również płeć. Wyższy poziom estrogenu u kobiet obniża aktywność enzymu konwertującego angiotensynę typu 2 (ACE2), co przekłada się na łagodniejszy przebieg choroby w porównaniu do płci męskiej [6]. Zaobserwowano, że zanieczyszczenie powietrza w danym regionie koreluje ze zwiększoną liczbą zakażeń SARS-CoV-2 [7]. Pod uwagę należy również wziąć aspekt społeczno-ekonomiczny, który niewątpliwie wpływa na zachorowalność [8]. Choć główne objawy choroby to gorączka, duszność, kaszel i nieżyt nosa, to zauważono, że układ oddechowy nie jest jedynym narażonym na infekcję. Wirusa wykryto bowiem w płynie mózgowo rdzeniowym (PMR) [9], co dowodzi, że może on infekować i uszkadzać także układ nerwowy. Istnieje kilka dróg, dzięki którym wirus jest w stanie wniknąć do układu nerwowego, a następnie zaburzyć jego funkcjonowanie.

\section{MECHANIZMY ZAKAZZENIA/USZKODZENIA OŚRODKOWEGO UKKADU NERWOWEGO (OUN)}

Jedną z przyczyn uszkodzenia OUN za pośrednictwem SARS-CoV-2 jest uraz wynikający z niedotlenienia. Replikacja wirusa w płucach powoduje miejscowe uszkodzenie pęcherzyków płucnych, co zaburza wymianę gazową i prowadzi do niedotlenienia OUN. Zwiększenie udziału metabolizmu beztlenowego w mózgu skutkuje obniżeniem $\mathrm{pH}$ środowiska. To z kolei prowadzi do rozszerzenia naczyń krwionośnych i obrzęku komórek nerwowych [10]. W przypadku przedłużającego się niedotlenienia obrzęk narasta, a przepływ krwi jest utrudniony. Może rozwinąć się nadciśnienie wewnątrzczaszkowe, prowadzące do stopniowego pogorszenia funkcji mózgu. Kolejną drogą, która pośredniczy w uszkodzeniu OUN jest układ odpornościowy. SARS-CoV-2 może bowiem infekować makrofagi, komórki mikrogleju oraz astrocyty. Aktywowane komórki mikrogleju wydzielają interleukinę 6 , interleukinę 12 , interleukinę 15 i TNF- $\alpha$ (tumor necrosis factor $\alpha$, czynnik martwicy nowotworów), [11] co prowadzi do powstania przewlekłego stanu zapalnego w OUN. Cytokiny produkowane przez objętą zakażeniem tkankę płucną, powodują również zwiększenie przepuszczalności bariery krew-mózg, umożliwiając penetrację wirusa do OUN. Uszkodzenie OUN przez SARS-CoV-2 umożliwia również fakt, że glikoproteina $\mathrm{S}$ wirusa ma zdolność wiązania $\mathrm{z}$ receptorem ACE2, obecnym między innymi na powierzchni komórek śródbłonka naczyń włosowatych [12, 13]. Pozwala to na wniknięcie wirusa do układu krążenia, a po przeniknięciu bariery krew-mózg, także do OUN. Wiązanie wirusa z receptorem ACE2 może powodować podwyższenie ciśnienia tętniczego krwi i zwiększać ryzyko udaru krwotocznego. Ekspresję ACE2 stwierdzono także m.in. na neuronach i komórkach glejowych w korze mózgowej, istocie czarnej, podwzgórzu, prążkowiu i pniu mózgu [14]. Ozna- cza to, że OUN może być potencjalnym bezpośrednim celem infekcji SARS-CoV-2. Wirus przedostaje się do OUN także poprzez neuronalny transport wsteczny [15]. Obecny na nabłonku nosa wirus wnika do zakończeń nerwu węchowego i przez opuszkę węchową przenika do OUN [16].

\section{OBJAWY NEUROLOGICZNE}

\section{Bóle głowy}

Jednym z częstszych objawów ze strony OUN jest ból głowy. Pojawia się średnio u około 8\% pacjentów, w zależności od danych literaturowych notowany jest w granicach od 6,5 do $23 \%$ [17]. W publikacji obejmującej 14 badań, z łączną liczbą pacjentów z COVID-19 wynoszącą 2863 , objaw ten został udokumentowany u $11,8 \%$. Warto zauważyć, że ryzyko wykrycia SARS-CoV-2 u pacjentów $\mathrm{z}$ incydentalnym bólem głowy było w tym badaniu 5 razy wyższe [18]. Przyczyny wystąpienia bólu głowy nie zostały dokładnie wyjaśnione. Dostrzeżono jednak zależność między współistniejącym zakażeniem SARS-CoV-2, a zaostrzeniem objawów występującej wcześniej w wywiadzie migreny [19].

Ból głowy u dzieci z towarzyszącym zmęczeniem i bólami mięśni stwierdzany jest w około $16,7 \%$ przypadków. Objawy te mimo swojej niskiej specyficzności są jednymi z najczęściej rejestrowanych w zakażeniu SARS-CoV-2 [20]. Przyczynami bólu głowy mogą być zakażenie ogólnoustrojowe, zapalenie dróg oddechowych, a także nasilenie migreny [21]. Izolowane bóle głowy przy braku innych charakterystycznych objawów towarzyszących zakażeniu SARS-CoV-2 u dzieci, były rejestrowane w 4-28\% przypadków [22]. W pracy Jeng i wsp. prezentującej 24 pacjentów z COVID-19 poniżej 20 roku życia, ból głowy był jednym z trzech najczęściej zgłaszanych objawów i występował u $25 \%$ chorych [23].

\section{Zespót Guillaina- Barrego}

Zespół Guilliana-Barrego (Guillain-Barre syndrome, GBS) to ostra poliradikulopatia, w przebiegu której występują objawy czuciowe, postępujące osłabienie mięśni oraz odwracalne niedowłady [24]. W pracy Hasan i wsp. przedstawiającej 61 pacjentów (w tym trzech pediatrycznych), średni czas pomiędzy wystąpieniem objawów COVID-19 i GBS wynosił 14 dni [25]. Czas trwania objawów GBS wahał się w granicach od 3 do 24 dni [26]. Opis przypadków pediatrycznych przedstawiono w tabeli I [24, 27, 28].

U dorosłych pacjentów zakażonych SARS-CoV-2 ze współistniejącym GBS, średni wiek wynosił 57,5 lat, a $64,3 \%$ badanych była płci męskiej. Najczęstszymi objawami klinicznymi GBS były osłabienie siły mięśniowej kończyn, hipo-/arefleksja 76,2 - 80,9\%, zaburzenia czucia $66,7 \%$, obwodowe porażenie nerwu twarzowego jednostronne- $38,1 \%$, a u $81,2 \%$ obustronne [29].

\section{Zaburzenia węchu i smaku}

Zaburzenia węchu oraz smaku są stosunkowo częstymi objawami w przebiegu zakażenia SARS-CoV-2 i mogą 
Tabela I. Zespót Guillaina-Barrego w przebiegu COVID-19 u dzieci.

Table. I. Guillain-Barré syndrome associated with COVID-19 in children.

\begin{tabular}{|c|c|c|c|}
\hline $\begin{array}{l}\text { Autorzy } \\
\text { Authors }\end{array}$ & Khalifa M. i wsp. & Frank C.H.M. i wsp. & Paybast S. i wsp. \\
\hline $\begin{array}{l}\text { Wiek (lata) } \\
\text { Age (years) }\end{array}$ & 11 & 15 & 14 \\
\hline $\begin{array}{l}\text { Płeć } \\
\text { Sex }\end{array}$ & męska & męska & żeńska \\
\hline $\begin{array}{l}\text { Objawy neurologiczne } \\
\text { Neurological symptoms }\end{array}$ & $\begin{array}{l}\text { zaburzenia chodu, parestezje, } \\
\text { w kończynach dolnych: osłabienie } \\
\text { sity mięśniowej, hipotonia, } \\
\text { zniesienie odruchów kolanowych } \\
\text { i skokowych, zaburzenia czucia } \\
\text { bólu i dotyku okolic stóp } \\
\text { obustronnie, } \\
\text { w kończynach górnych: } \\
\text { odruchy ścięgnisto-okostnowe } \\
\text { wygórowane }\end{array}$ & $\begin{array}{l}\text { ból głowy, uogólnione osłabienie } \\
\text { sity mięśniowej, zniesione } \\
\text { odruchy ścięgnisto-okostnowe }\end{array}$ & $\begin{array}{l}\text { osłabienie siły mięśniowej kończyn } \\
\text { dolnych, bóle i zawroty gtowy, } \\
\text { odruchy ścięgnisto-okostnowe: } \\
\text { osłabienie w kończynach górnych } \\
\text { i zniesienie w kończynach dolnych, } \\
\text { osłabienie czucia dotyku i wibracji } \\
\text { we wszystkich kończynach }\end{array}$ \\
\hline EMG & $\begin{array}{l}\text { ENG - obniżona prędkość } \\
\text { przewodzenia w nerwach } \\
\text { ruchowych z niską amplitudą } \\
\text { odpowiedzi, zaburzenia } \\
\text { przewodzenia czuciowego, brak } \\
\text { fali F, } \\
\text { tydzień po zakończeniu } \\
\text { hospitalizacji: poprawa w zakresie } \\
\text { prędkości przewodzenia i amplitud }\end{array}$ & $\begin{array}{l}\text { zmniejszenie amplitudy } \\
\text { potencjału czynnościowego } \\
\text { w nerwach ruchowych przy } \\
\text { zachowanych prędkościach } \\
\text { przewodzenia oraz brak fali F }\end{array}$ & brak danych \\
\hline $\begin{array}{l}\text { Czas trwania objawów } \\
\text { neurologicznych } \\
\text { Duration of neurological } \\
\text { symptoms }\end{array}$ & $\begin{array}{l}\text { w } 15 \text { dobie zakończenie } \\
\text { hospitalizacji, stopniowa poprawa } \\
\text { siły motorycznej, utrzymująca się } \\
\text { hiporefleksja }\end{array}$ & $\begin{array}{l}\text { po } 15 \text { dniach - utrzymujące } \\
\text { się osłabienie kończyn mimo } \\
\text { leczenia IVIG }\end{array}$ & $\begin{array}{l}\text { zakończenie hospitalizacji w stanie } \\
\text { dobrym z uogólnioną hiporefleksją } \\
\text { i osłabieniem czucia dotyku } \\
\text { w dystalnych częściach kończyn }\end{array}$ \\
\hline $\begin{array}{l}\text { Objawy towarzyszące } \\
\text { Other symptoms }\end{array}$ & $\begin{array}{l}\text { miesiąc wcześniej przebyta ostra } \\
\text { infekcja dróg oddechowych z niską } \\
\text { gorączką i uporczywym suchym } \\
\text { kaszlem, } \\
\text { wysypka skórna (bez świądu) na } \\
\text { dłoniach towarzysząca objawom } \\
\text { neurologicznym, RTG klatki } \\
\text { piersiowej - obraz mlecznej szyby } \\
\text { (obustronnie) }\end{array}$ & wymioty, gorączka & brak \\
\hline $\begin{array}{l}\text { Test w kierunku COVID-19 } \\
\text { COVID-19 test }\end{array}$ & RT-PCR (+) & $\begin{array}{l}\text { test serologiczny } \lg \mathrm{G} \text { i } \lg M(+) \text {, } \\
\text { RT-PCR }(+)\end{array}$ & RT-PCR (+) \\
\hline
\end{tabular}

Skróty zastosowane w tabeli I: *EMG - electromyography - elektromiografia, ${ }^{* *}$ ENG - electroneurography elektroneurografia, ${ }^{* *}$ RTG - zdjęcie rentgenowskie, ${ }^{* * *}$ RT-PCR - reverse transcriptase polymerase chain reaction reakcja łańcuchowa polimerazy z odwrotną transkryptazą, ${ }^{* * * *} I V I G$ - intravenous immunoglobulines - dożylne preparaty immunoglobulin ludzkich 
wystąpić nagle lub stopniowo się nasilać. W analizie dokonanej na podstawie specjalnie zaprojektowanych kwestionariuszy stwierdzono, że nagły początek anosmii występował u 76\% badanych, z kolei postępujące osłabienie węchu zarejestrowano u 60\% ankietowanych [30]. W badaniu obejmującym 57 dorosłych utrata węchu pojawiająca się w pierwszym dniu choroby lub występująca jako pierwszy objaw COVID-19 była rejestrowana u 73,9\% badanych. Zaburzenia smaku pojawiły się zaledwie u 8,7\% pacjentów [31]. Zaburzenia węchu rzadko współistniały z towarzyszącym nieżytem nosa lub obrzękiem małżowin nosowych. Najczęściej stanowiły odwracalny objaw, a powrót węchu następował w przeciągu kilku tygodni [32] W badaniu obejmującym 394 osoby, zaburzenia węchu i/ lub smaku występowały u 161 (41\%) osób, z czego 6\% stanowiły dzieci. Izolowane dysfunkcje węchu lub smaku miały miejsce u 10\%, a w 19\% poprzedzały inne charakterystyczne dla COVID-19 objawy [33]. W badaniu przeprowadzonym pośród 177 dzieci utratę węchu i/lub smaku zarejestrowano u 15, czyli u 9\% pacjentów [34]. W badaniu przedstawiającym 24 osoby z COVID-19 poniżej 20 roku życia, utrata węchu lub smaku pojawiła się u $3 \mathrm{z}$ nich [23]. W teście przeprowadzonym w 20-osobowej grupie dzieci po zakażeniu SARS-CoV-2 zaburzenia węchu były częstsze niż całkowita utrata odczuwania zapachów, a także pojawiały się częściej niż w grupie kontrolnej składającej się z 48 zdrowych dzieci [35].

Kwestia subiektywnego odbierania wrażeń smakowych i zapachowych u dzieci znacznie utrudnia ich ocenę, szczególnie u najmłodszych pacjentów (tab. II) [36-40].

U dorosłych zaburzenia węchu i smaku są częstsze niż w populacji pediatrycznej i występują u około 38-41\% przypadków z potwierdzonym COVID-19. Warto zauważyć, że nie zarejestrowano zależności pomiędzy częstością zgłaszania tych objawów a płcią. Zaburzenia te mogą być jedynymi objawami sugerującymi zakażenie SARS-CoV-2 lub współistnieć z innymi charakterystycznymi dla tej jednostki chorobowej. Ich wartość diagnostyczna, zwłaszcza brak węchu, oceniana jest na 23-43\% czułości oraz 9399\% specyficzności [41].

\section{INFEKCJE OŚRODKOWEGO UKŁADU NERWOWEGO}

\section{Wirusowe zapalenie opon mózgowo-rdzeniowych, poprzeczne zapale- nie rdzenia kręgowego}

Wirusowe zapalenie opon mózgowo-rdzeniowych (ZOMR) to jałowe lub limfocytowe zapalenie opon wywołane infekcją wirusową. W przebiegu choroby może wystąpić gorączka, światłowstręt, dodatnie objawy oponowe, objawy zespołu wzmożonego ciśnienia wewnątrzczaszkowego, a także zaburzenia świadomości, uogólnione lub ogniskowe napady padaczkowe oraz niedowłady kończyn [42].

ZOMR i poprzeczne zapalenie rdzenia kręgowego nie są częstymi objawami towarzyszącymi COVID-19 - zarówno u dorosłych, jak i dzieci. Charakterystykę opisanych w piśmiennictwie zaburzeń występujących u dzieci przedstawiono w tabeli III [43-47].

\section{Zapalenie mózgu}

W etiologii zapalenia mózgu najważniejszą rolę odgrywają wirusy. Aby ustalić rozpoznanie należy wziąć pod uwagę pojawiające się nagle objawy kliniczne z towarzyszącymi zaburzeniami świadomości oraz ogniskowe deficyty neurologiczne. Za pomocą badań pomocniczych można wykazać zmiany w PMR, nieprawidłowości w badaniach neuroobrazowych oraz zaburzenia w zapisie elektroencefalograficznym (EEG) [48]. Wykrycie kopii SARS-CoV-2 w PMR może być trudne z uwagi na niskie stężenie [49].

Zapalenie mózgu nie jest częstym powikłaniem COVID-19 u dzieci. Przypadki opisane w piśmiennictwie medycznym, wraz z krótką charakterystyką, przedstawiono w tabeli IV [50-52].

W populacji dorosłych zapalenie mózgu również nie jest częstym objawem towarzyszącym COVID-19. Opisano zaledwie kilka przypadków, a towarzyszące im objawy były charakterystyczne dla zapalenia mózgu. Rejestrowane były średnio po 17 dniach od wystąpienia objawów ze strony układu oddechowego spowodowanych zakażeniem SARS-CoV-2 [48].

\section{Zmiany naczyniowe}

W populacji dorosłych zmiany naczyniowe OUN są jednym z częściej występujących powikłań neurologicznych. Jako przyczynę udarów w przebiegu COVID-19 wskazuje się wysokie powinowactwo SARS-CoV-2 do receptora ACE2, uszkodzenie śródbłonka, koagulopatie, nadkrzepliwość i zaburzenia przepływu żylnego [53].

Ogniskowe arteriopatie dużych tętnic opisywane są jako główny czynnik wywołujący udary niedokrwienne mózgu u dzieci niewykazujących wcześniej żadnych objawów, a ich przyczyn upatruje się w czynnikach infekcyjnych [54].

Ponadto jako powikłanie COVID-19 wskazano inne zmiany naczyniowe. Zestawienie opisanych w piśmiennictwie pacjentów zamieszczono w tabeli V [55-60].

Beslow i wsp. na podstawie analizy wieloośrodkowej wykazali, że u 4,7\% pacjentów pediatrycznych, u których wystąpił udar, zdiagnozowano zakażenie SARS-CoV-2 [60]. Warto jednak zaznaczyć, że test potwierdzający zakażenie wykonano w mniej niż 50\% przypadków.

Dokładny patomechanizm zmian naczyniowych w przebiegu COVID-19 jest niejasny i wymaga dalszych analiz. Jedną z sugerowanych przyczyn jest wzrost stężenia cytokin (głównie interelukiny 6 , interleukiny 13 i TNF $\alpha$ [61]), mogący powodować uszkodzenie śródbłonka naczyń, a tym samym prowadzić do wyżej wymienionych patologii [59].

\section{Drgawki/ napady padaczkowe}

Dotąd opisano tylko kilkanaście przypadków wystąpienia drgawek bądź napadów/stanów padaczkowych u dzieci i adolescentów zakażonych SARS-CoV-2.

Drgawki gorączkowe są zjawiskiem często obserwowanym u dzieci, ze względu na wrażliwość rozwijającego się układu nerwowego na podwyższoną temperaturę ciała [62]. Wykazuje się związek między wysokim stęże- 
Tabela II. Zaburzenia węchu i smaku w przebiegu COVID-19 w populacji pediatrycznej.

Table. II. Smell and taste disorders associated with COVID-19 in the pediatric population.

\begin{tabular}{|c|c|c|c|c|c|c|c|c|c|}
\hline $\begin{array}{l}\text { Autorzy } \\
\text { Authors }\end{array}$ & $\begin{array}{l}\text { Mak P.Q. } \\
\text { i wsp. }\end{array}$ & $\begin{array}{l}\text { Mak P.Q. } \\
\text { i wsp. }\end{array}$ & $\begin{array}{l}\text { Mak P.Q. } \\
\text { i wsp. }\end{array}$ & $\begin{array}{l}\text { Maniaci A. } \\
\text { i wsp. }\end{array}$ & $\begin{array}{l}\text { Hatipoglu N. } \\
\text { i wsp. }\end{array}$ & $\begin{array}{l}\text { Hatipoglu N. } \\
\text { i wsp. }\end{array}$ & $\begin{array}{l}\text { Hatipoglu } \\
\text { N. i wsp. }\end{array}$ & $\begin{array}{l}\text { Marhaeni W. } \\
\text { i wsp }\end{array}$ & $\begin{array}{l}\text { Kasuga Y. } \\
\text { i wsp. }\end{array}$ \\
\hline $\begin{array}{l}\text { Wiek (lata) } \\
\text { Age (years) }\end{array}$ & 15 & 14 & 17 & 15 & 13 & 13 & 13 & 17 & 13 \\
\hline $\begin{array}{l}\text { Płeć } \\
\text { Sex }\end{array}$ & żeńska & męska & żeńska & męska & żeńska & męska & męska & żeńska & żeńska \\
\hline $\begin{array}{l}\text { Objawy } \\
\text { neurologiczne } \\
\text { Neurological } \\
\text { symptoms }\end{array}$ & $\begin{array}{l}\text { utrata } \\
\text { smaku } \\
\text { i węchu }\end{array}$ & $\begin{array}{l}\text { utrata } \\
\text { węchu }\end{array}$ & $\begin{array}{l}\text { nagła } \\
\text { utrata } \\
\text { smaku } \\
\text { i węchu, } \\
\text { ból głowy }\end{array}$ & $\begin{array}{l}\text { zaburzenia } \\
\text { węchu, } \\
\text { zaburzenia } \\
\text { smaku - } \\
\text { metaliczny } \\
\text { posmak, ból } \\
\text { głowy }\end{array}$ & $\begin{array}{l}\text { utrata } \\
\text { węchu, ból } \\
\text { głowy }\end{array}$ & $\begin{array}{l}\text { brak węchu } \\
\text { i smaku }\end{array}$ & $\begin{array}{l}\text { ból głowy, } \\
\text { zaburzenia } \\
\text { węchu } \\
\text { i smaku }\end{array}$ & $\begin{array}{l}\text { utrata } \\
\text { smaku } \\
\text { i osłabienie } \\
\text { węchu }\end{array}$ & $\begin{array}{l}\text { nagła } \\
\text { utrata } \\
\text { węchu } \\
\text { i smaku }\end{array}$ \\
\hline $\begin{array}{l}\text { Czas trwania } \\
\text { objawów } \\
\text { neurolo- } \\
\text { gicznych } \\
\text { Duration of } \\
\text { neurological } \\
\text { symptoms }\end{array}$ & $\begin{array}{l}\text { smak - } 8 \\
\text { dni } \\
\text { węch } \\
\text { - brak } \\
\text { danych }\end{array}$ & $3 \mathrm{dni}$ & $7 \mathrm{dni}$ & 12 dni & $\begin{array}{l}4 \text { dni bez } \\
\text { leczenia }\end{array}$ & $3 \mathrm{dni}$ & $\begin{array}{l}\text { brak } \\
\text { danych }\end{array}$ & $\begin{array}{l}\text { brak } \\
\text { danych }\end{array}$ & $\begin{array}{l}\text { od } 14 \text { dnia } \\
\text { choroby } \\
\text { poprawa } \\
\text { funkcji } \\
\text { smakowych } \\
\text { i węchowych, } \\
\text { całkowita } \\
\text { poprawa } \\
\text { po } 18 \text { dniach }\end{array}$ \\
\hline $\begin{array}{l}\text { Objawy } \\
\text { towarzyszące } \\
\text { Other } \\
\text { symptoms }\end{array}$ & $\begin{array}{l}\text { wydzielina } \\
\text { surowicza } \\
\text { z nosa }\end{array}$ & $\begin{array}{l}\text { wydzielina } \\
\text { surowicza } \\
\text { z nosa, } \\
\text { w } \\
\text { wywiadzie } \\
\text { alergiczny } \\
\text { nieżyt } \\
\text { nosa }\end{array}$ & $\begin{array}{l}\text { ból } \\
\text { w klatce } \\
\text { piersiowej, } \\
\text { wymioty }\end{array}$ & $\begin{array}{l}\text { utrata } \\
\text { apetytu, } \\
\text { zmiany } \\
\text { rumieniowe } \\
\text { skóry } \\
\text { kończyn } \\
\text { dolnych, } \\
\text { gorączka, ból } \\
\text { gardła i szyi, } \\
\text { przekrwienie } \\
\text { błony } \\
\text { śluzowej } \\
\text { nosa, } \\
\text { wydzielina } \\
\text { surowicza } \\
\text { z nosa }\end{array}$ & $\begin{array}{l}\text { zaburzenia } \\
\text { oddychania, } \\
\text { w TK obraz } \\
\text { wirusowego } \\
\text { zapalenia } \\
\text { płuc }\end{array}$ & $\begin{array}{l}\text { gorączka, } \\
\text { TK klatki } \\
\text { piersiowej } \\
\text { - obraz } \\
\text { mlecznej } \\
\text { szyby }\end{array}$ & $\begin{array}{l}\text { gorączka, } \\
\text { kaszel, } \\
\text { ostabienie, } \\
\text { ból } \\
\text { w klatce } \\
\text { piersiowej, } \\
\text { MR klatki } \\
\text { piersiowej } \\
\text { - obraz } \\
\text { zapalenia } \\
\text { płuc }\end{array}$ & $\begin{array}{l}\text { infekcja } \\
\text { górnych dróg } \\
\text { oddecho- } \\
\text { wych, bóle } \\
\text { mięśniowe, } \\
\text { w wywiadzie } \\
\text { rozpoznana } \\
\text { beta- } \\
\text { talasemia }\end{array}$ & $\begin{array}{l}\text { gorączka, } \\
\text { kaszel }\end{array}$ \\
\hline $\begin{array}{l}\text { Test } \\
\text { w kierunku } \\
\text { COVID-19 } \\
\text { COVID-19 test }\end{array}$ & $\begin{array}{l}\text { RT-PCR } \\
(+)\end{array}$ & $\begin{array}{l}\text { RT-PCR } \\
(+)\end{array}$ & $\begin{array}{l}\text { RT-PCR } \\
(+)\end{array}$ & $\begin{array}{l}\text { RT-PCR } \\
(+)\end{array}$ & $\begin{array}{l}\text { RT-PCR } \\
(+)\end{array}$ & $\begin{array}{l}\text { kontakt } \\
\text { z osobą } \\
\text { COVID-19 } \\
(+)\end{array}$ & $\begin{array}{l}\text { pobrano } \\
\text { wymaz } \\
\text { w kierunku } \\
\text { COVID-19 } \\
\text {-brak } \\
\text { danych } \\
\text { o wyniku }\end{array}$ & $\begin{array}{l}\text { RT-PCR } \\
(+)\end{array}$ & $\begin{array}{l}\text { RT-PCR } \\
(+)\end{array}$ \\
\hline
\end{tabular}

Skróty zastosowane w tabeli II: *TK - computed tomography - tomografia komputerowa, ${ }^{* *} \mathrm{MR}$ - magnetic resonance rezonans magnetyczny, ${ }^{* * *}$ COVID-19 - corona virus disease 2019 
Tabela III. Zapalenie opon mózgowo- rdzeniowych i poprzeczne zapalenie rdzenia kręgowego w przebiegu COVID-19 w populacji pediatrycznej.

Table III. Meningo-spinal cord inflammation and transverse myelitis associated with COVID-19 in the pediatric population.

\begin{tabular}{|c|c|c|c|c|c|}
\hline $\begin{array}{l}\text { Autorzy } \\
\text { Authors }\end{array}$ & Oualha M. i wsp. & Kest H. i wsp. & Freij B.J. i wsp. & Kaur H. i wsp & Yousefi K. i wsp. \\
\hline $\begin{array}{l}\text { Wiek (lata) } \\
\text { Age (years) }\end{array}$ & 16 & 9 & 5 & 9 & 3 \\
\hline $\begin{array}{l}\text { Płeć } \\
\text { Sex }\end{array}$ & męska & męska & żeńska & żeńska & żeńska \\
\hline $\begin{array}{l}\text { Objawy } \\
\text { neurologiczne } \\
\text { Neurological } \\
\text { symptoms }\end{array}$ & $\begin{array}{l}\text { GCS 11, w } 4 \\
\text { dobie: niedowład } \\
\text { połowiczy } \\
\text { (udar z zakresu } \\
\text { unaczynienia lewej } \\
\text { tętnicy środkowej } \\
\text { mózgu), w } 7 \text { dobie } \\
\text { śpiączka }\end{array}$ & brak & $\begin{array}{l}\text { ból głowy, epizod } \\
\text { dezorientacji z tonicznym } \\
\text { wzrostem napięcia } \\
\text { w kończynach dolnych, } \\
\text { encefalopatia, w } 15 \text { dobie: } \\
\text { zaburzenia świadomości, } \\
\text { asymetria źrenic }\end{array}$ & $\begin{array}{l}\text { bóle głowy, } \\
\text { sztywność } \\
\text { karku, objawy } \\
\text { oponowe (+), } \\
\text { światłowstręt, } \\
\text { diplopia, } \\
\text { porażenie } \\
\text { prawego nerwu } \\
\text { odwodzącego }\end{array}$ & $\begin{array}{l}\text { wiotkie porażenie } \\
\text { czterokończynowe, } \\
\text { arefleksja }\end{array}$ \\
\hline $\begin{array}{l}\text { Badanie MR } \\
\text { głowy/rdzenia } \\
\text { kręgowego } \\
\text { MR } \\
\text { examination } \\
\text { of the head/ } \\
\text { spinal cord }\end{array}$ & $\begin{array}{l}\text { MR głowy: } \\
\text { zapalenie zatok } \\
\text { klinowych, } \\
\text { zakrzepica zatoki } \\
\text { jamistej }\end{array}$ & brak danych & $\begin{array}{l}\text { MR głowy: } 7 \text { mm } \\
\text { obszar ograniczonej } \\
\text { dyfuzji w podkorowej } \\
\text { istocie białej płata } \\
\text { czołowego z podwyższoną } \\
\text { intensywnością sygnału } \\
\text { w T2 FLAIR, wzmocnienie } \\
\text { pokontrastowe opon } \\
\text { mózgowo-rdzeniowych } \\
\text { w } 16 \text { dobie: rozległa } \\
\text { progresja ZOMR do móżdżku } \\
\text { i ciała modzelowatego, } \\
\text { w } 30 \text { dobie: postęp } \\
\text { zapalenia z obrzękiem } \\
\text { nadnamiotowym } \\
\text { i podnamiotowym, zmiany } \\
\text { niedokrwienne, wgtobienie } \\
\text { migdałków móżdżku do } \\
\text { otworu wielkiego }\end{array}$ & brak danych & $\begin{array}{l}\text { MR rdzenia } \\
\text { kręgowego: obrzęk } \\
\text { odcinka szyjnego } \\
\text { rdzenia kręgowego, } \\
\text { w sekwencji } \\
\text { SET2 widoczny } \\
\text { hiperintensywny } \\
\text { obrzęk obejmujący } \\
\text { większość przekroju } \\
\text { poprzecznego rdzenia } \\
\text { kręgowego, od } \\
\text { dolnego odcinka } \\
\text { rdzenia } \\
\text { przedłużonego do } \\
\text { środkowego poziomu } \\
\text { odcinka piersiowego }\end{array}$ \\
\hline $\begin{array}{l}\text { Rozpoznanie } \\
\text { Diagnosis }\end{array}$ & $\begin{array}{l}\text { ZOMR } \\
\text { aseptyczne }\end{array}$ & $\begin{array}{l}\text { ZOMR } \\
\text { aseptyczne }\end{array}$ & ZOMR & ZOMR & $\begin{array}{l}\text { poprzeczne zapalenie } \\
\text { rdzenia kręgowego }\end{array}$ \\
\hline $\begin{array}{l}\text { Czas trwania } \\
\text { objawów } \\
\text { neurolo- } \\
\text { gicznych } \\
\text { Duration of } \\
\text { neurological } \\
\text { symptoms }\end{array}$ & 17 dni (zgon) & brak danych & 32 dni (zgon) & $10 \mathrm{dni}$ & brak danych \\
\hline $\begin{array}{l}\text { Objawy } \\
\text { towarzyszące } \\
\text { Other } \\
\text { symptoms }\end{array}$ & brak & $\begin{array}{l}\text { gorączka, biegunka, } \\
\text { wymioty, duszność, } \\
\text { zapalenie spojówek, } \\
\text { obrzęk twarzy, } \\
\text { niewydolność } \\
\text { oddechowa, } \\
\text { upośledzenie funkcji } \\
\text { nerek, upośledzona } \\
\text { czynność skurczowa } \\
\text { serca }\end{array}$ & $\begin{array}{l}\text { gorączka, SIADH, } \\
\text { nadciśnienie, RTG klatki } \\
\text { piersiowej: obraz mlecznej } \\
\text { szyby w obrębie wnęk płuc }\end{array}$ & $\begin{array}{l}\text { gorączka, ból } \\
\text { pleców }\end{array}$ & $\begin{array}{l}\text { niewydolność } \\
\text { oddechowa }\end{array}$ \\
\hline $\begin{array}{l}\text { Test } \\
\text { w kierunku } \\
\text { COVID-19 } \\
\text { COVID-19 test }\end{array}$ & $\begin{array}{l}\text { RT-PCR (+), PMR } \\
\text { - brak danych }\end{array}$ & $\operatorname{PMR}(+)$ & RT-PCR (+), PMR (-) & PMR $(+)$ & RT-PCR (+), PMR (-) \\
\hline
\end{tabular}

Skróty zastosowane w tabeli III: *GCS - Glasgow Coma Scale - skala Glasgow, ${ }^{*}$ FLAIR - fluid-attenuated inversioin recovery, ${ }^{* * * Z O M R ~-~}$ zapalenie opon mózgowo-rdzeniowych, ${ }^{* * *}$ PMR - płyn mózgowo-rdzeniowy, ${ }^{* * * *}$ SIADH - syndrome of inappropriate antidiuretic hormone secretion - zespół nieadekwatnego wydzielania wazopresyny 
Tabela IV. Zapalenie mózgu w przebiegu COVID-19 w populacji pediatrycznej. Table IV. Encephalitis associated with COVID-19 in the pediatric population.

\begin{tabular}{|c|c|c|c|}
\hline $\begin{array}{l}\text { Autorzy } \\
\text { Authors }\end{array}$ & $\begin{array}{l}\text { Conto-Palomino N.M. } \\
\text { i wsp. }\end{array}$ & McAbee G.N. i wsp. & de Miranda Henriques-Souza A.M. i wsp \\
\hline $\begin{array}{l}\text { Wiek (lata) } \\
\text { Age (years) }\end{array}$ & 13 & 11 & 12 \\
\hline $\begin{array}{l}\text { Płeć } \\
\text { Sex }\end{array}$ & żeńska & męska & żeńska \\
\hline $\begin{array}{l}\text { Objawy } \\
\text { neurologiczne } \\
\text { Neurological } \\
\text { symptoms }\end{array}$ & $\begin{array}{l}\text { ból głowy, zaburzenia } \\
\text { czucia i równowagi, } \\
\text { niedowład połowiczy }\end{array}$ & izolowany napad padaczkowy & $\begin{array}{l}\text { ból głowy, niedowład wiotki czterokończynowy, } \\
\text { zniesione odruchy: oczno-głowowy, rogówkowy, } \\
\text { kaszlowy, gardłowy, brzuszny, podeszwowy, } \\
\text { po } 68 \text { dniach: tetraplegia spastyczna, objaw Babińskiego } \\
\text { obustronnie dodatni, nietrzymanie moczu }\end{array}$ \\
\hline $\begin{array}{l}\text { Badania } \\
\text { neuroobrazowe } \\
\text { Neuroimaging } \\
\text { examination }\end{array}$ & $\begin{array}{l}\text { TK głowy - } \\
\text { uogólniony obrzęk } \\
\text { mózgu }\end{array}$ & TK głowy- brak zmian & $\begin{array}{l}\text { MR głowy - symetryczne, obustronne obszary } \\
\text { ograniczonej dyfuzji w obrębie podkorowej i głębokiej } \\
\text { istoty białej, w sekwencji T2 i FLAIR ogniskowa } \\
\text { hiperintensywność z ograniczoną dyfuzją w obrębie ciała } \\
\text { modzelowatego, w MR odcinka szyjnego kręgosłupa - } \\
\text { mielopatia w obrębie istoty białej i szarej }\end{array}$ \\
\hline $\begin{array}{l}\text { Płyn mózgowo- } \\
\text { rdzeniowy } \\
\text { Cerebrospinal fluid }\end{array}$ & $\begin{array}{l}\text { glukoza } 98 \mu \mathrm{g} / \\
\text { dl, białko } 45 \mu \mathrm{g} / \\
\text { dl, cytoza } 6 / \mathrm{mm} 3 \\
\text { (80\% komórek } \\
\text { jednojądrzastych) }\end{array}$ & $\begin{array}{l}\text { glukoza } 92 \text { mg/dl, białko } \\
97 \mathrm{mg} / \mathrm{dl}, \text { neutrofile } 8 \% \text {, } \\
\text { erytrocyty } 921 \text {, leukocyty } 16\end{array}$ & białko 18 mg/dl, glukoza 74 mg/dl \\
\hline $\begin{array}{l}\text { Rozpoznanie } \\
\text { Diagnosis }\end{array}$ & zapalenie mózgu & zapalenie mózgu & ostre rozsiane zapalenie mózgu i rdzenia \\
\hline $\begin{array}{l}\text { Czas trwania } \\
\text { objawów neurolo- } \\
\text { gicznych } \\
\text { Duration of } \\
\text { neurological } \\
\text { symptoms }\end{array}$ & 6 dni (zgon) & 6 dni & ból głowy - 1 dzień \\
\hline $\begin{array}{l}\text { Objawy } \\
\text { towarzyszące } \\
\text { Other symptoms }\end{array}$ & gorączka, wymioty & gorączka, osłabienie & $\begin{array}{l}\text { wysypka, gorączka, niewydolność oddechowa, w LDCT } \\
\text { ogniskowa niedodma płata dolnego płuca prawego }\end{array}$ \\
\hline $\begin{array}{l}\text { Test w kierunku } \\
\text { COVID-19 } \\
\text { COVID-19 test }\end{array}$ & test serologiczny $(+)$ & RT-PCR $(+)$ & RT-PCR (+) \\
\hline
\end{tabular}

Skróty zastosowane w tabeli IV: *LDCT - low-dose computed tomography - niskodawkowa tomografia komputerowa klatki piersiowej

niem cytokin w przebiegu gorączki a wystąpieniem drgawek [63, 64]. Pojawiają się one zwykle w pierwszym dniu wystąpienia gorączki powyżej $38^{\circ} \mathrm{C}$ [62]. Na szczególną uwagę zasługują również przypadki drgawek w przebiegu opisanego poniżej wieloukładowego zespołu zapalnego.

W przebiegu COVID-19 występują drgawki różnego pochodzenia oraz napady padaczkowe, co przedstawiono w tabeli VI [64-72].

Włoskie badanie wieloośrodkowe obejmujące 168 dzieci wykazało występowanie drgawek u pięciorga z nich, z czego troje było wcześniej leczonych z powodu padaczki [73].

Do tej pory nie przedstawiono dokładnych wyników badań określających możliwości nasilenia napadów padaczkowych u dzieci ze zdiagnozowaną padaczką, dlatego nie można ocenić w jaki sposób infekcja SARS-CoV-2 wpływa na ich przebieg. U dorosłych nie stwierdzono zwiększonego ryzyka napadów, ich nasilenia ani innych niekorzystnych korelacji w związku z zakażeniem [74].

Ze względu na potencjalny neurotropizm SARS-CoV-2 u części pacjentów wykonano badanie PMR w kierunku obecności w nim kopii wirusa. U znacznej części zakażenie nie zostało potwierdzone. Za potencjalną przyczynę zaburzeń przyjmuje się reakcje autoimmunologiczne, gorączkę bądź też obecność kopii wirusa w PMR, nawet w przypadku ujemnego wyniku testu [75].

\section{Encefalopatie}

U części badanych zaobserwowano encefalopatie związane z cytotoksycznym uszkodzeniem ciała modzelowatego. Do takiego, zwykle odwracalnego [76] uszkodzenia, dochodzi m.in. w wyniku infekcji, gdy stwierdza się patologiczny wzrost stężenia cytokin (głównie interleukiny 
Tabela V. Zmiany naczyniowe w przebiegu COVID-19 w populacji pediatrycznej.

Table V. Vascular disorders associated with COVID-19 in the pediatric population.

\begin{tabular}{|c|c|c|c|c|c|c|}
\hline $\begin{array}{l}\text { Autorzy } \\
\text { Authors }\end{array}$ & $\begin{array}{l}\text { Mirzaee } \\
\text { S.M.M. i wsp. }\end{array}$ & Gulko E. i wsp. & Kihira S. i wsp. & Dakay K. i wsp. & Savić D. i wsp. & $\begin{array}{l}\text { Beslow L.A. } \\
\text { i wsp }\end{array}$ \\
\hline $\begin{array}{l}\text { Wiek } \\
\text { Age }\end{array}$ & 12 lat & 13 lat & 5 lat & 17 lat & 13 lat & 4 dni \\
\hline $\begin{array}{l}\text { Płeć } \\
\text { Sex }\end{array}$ & męska & żeńska & męska & męska & żeńska & żeńska \\
\hline $\begin{array}{l}\text { Objawy } \\
\text { neurologiczne } \\
\text { Neurological } \\
\text { symptoms }\end{array}$ & $\begin{array}{l}\text { uogólniony } \\
\text { napad } \\
\text { drgawkowy, } \\
\text { prawostronny } \\
\text { niedowład } \\
\text { połowiczy, } \\
\text { dyzartria }\end{array}$ & $\begin{array}{l}\text { uporczywy ból } \\
\text { głowy, osłabienie } \\
\text { kończyn prawych, } \\
\text { zaburzenia } \\
\text { płynności } \\
\text { mowy, trudność } \\
\text { w znajdowaniu } \\
\text { słów }\end{array}$ & $\begin{array}{l}\text { anizokoria }(\mathrm{OL}>0 \mathrm{P}) \\
\text { z brakiem reakcji na } \\
\text { światło po stronie lewej }\end{array}$ & $\begin{array}{l}\text { bóle głowy, niewyraźne } \\
\text { widzenie }\end{array}$ & $\begin{array}{l}\text { utrata przytomności, } \\
\text { niedowład } \\
\text { prawostronny }\end{array}$ & brak danych \\
\hline $\begin{array}{l}\text { Rozpoznanie } \\
\text { Diagnosis }\end{array}$ & $\begin{array}{l}\text { ostry udar } \\
\text { niedokrwienny, } \\
\text { ogniskowe } \\
\text { proksymalne } \\
\text { zwężenie lewej } \\
\text { MCA (odcinek } \\
\text { M1) }\end{array}$ & $\begin{array}{l}\text { zmiany } \\
\text { niedokrwienne } \\
\text { w obrębie } \\
\text { unaczynienia lewej } \\
\text { MCA, ogniskowe } \\
\text { zwężenie lewej } \\
\text { MCA (segment } \\
\text { M1), pogrubienie } \\
\text { ściany tętnicy oraz } \\
\text { koncentryczne } \\
\text { wzmocnienie } \\
\text { pokontrastowe } \\
\text { w odcinku M1 }\end{array}$ & $\begin{array}{l}\text { udar niedokrwienny } \\
\text { prawych ACA } \\
\text { i MCA, krwotok } \\
\text { podpajęczynówkowy } \\
\text { w obrębie lewej półkuli } \\
\text { mózgu }\end{array}$ & $\begin{array}{l}\text { zakrzepica zatok żylnych } \\
\text { opony twardej, zakrzep } \\
\text { w lewej żyle zespalającej } \\
\text { dolnej, obrzęk tarczy } \\
\text { nerwu wzrokowego }\end{array}$ & $\begin{array}{l}\text { tętniak rzekomy } \\
\text { czołowo-ciemieniowej } \\
\text { gałęzi MCA } \\
\text { (odcinek M2) } \\
\text { z rozwarstwieniem, } \\
\text { krwotok } \\
\text { śródczaszkowy }\end{array}$ & $\begin{array}{l}\text { udar } \\
\text { niedokrwienny } \\
\text { wzgórzowo- } \\
\text { torebkowy }\end{array}$ \\
\hline $\begin{array}{l}\text { Czas trwania } \\
\text { objawów } \\
\text { neurolo- } \\
\text { gicznych } \\
\text { Duration of } \\
\text { neurological } \\
\text { symptoms }\end{array}$ & $\begin{array}{l}\text { utrzymująca } \\
\text { się } \\
\text { hemipareza, } \\
\text { pacjent } \\
\text { w trakcie } \\
\text { rehabilitacji }\end{array}$ & brak danych & zgon po 3 dobach & $\begin{array}{l}\text { w } 10 \text { dobie zakończono } \\
\text { hospitalizację, po } \\
\text { dwóch tygodniach - } \\
\text { przemijające zaburzenia } \\
\text { widzenia }\end{array}$ & GCS: $12-7-8-4$ & brak danych \\
\hline $\begin{array}{l}\text { Objawy } \\
\text { towarzyszące } \\
\text { Other } \\
\text { symptoms }\end{array}$ & brak & $\begin{array}{l}\text { dwa miesiące } \\
\text { przed hospitalizacją } \\
\text { - gorączka, bóle } \\
\text { mięśni, anosmia }\end{array}$ & $\begin{array}{l}\text { gorączka, kaszel, } \\
\text { ból brzucha, wstrząs } \\
\text { kardiogenny, } \\
\text { w RTG uwydatnienie } \\
\text { naczyń oskrzelowych, } \\
\text { kardiomegalia }\end{array}$ & $\begin{array}{l}\text { sporadycznie } \\
\text { występujące wymioty, } \\
\text { nadkrzepliwość }\end{array}$ & $\begin{array}{l}\text { gorączka, ARDS, } \\
\text { hepatomegalia, } \\
\text { splenomegalia } \\
\text { z zawałem śledziony, } \\
\text { obustronna nefropatia, } \\
\text { wodobrzusze }\end{array}$ & brak \\
\hline $\begin{array}{l}\text { Test w kierunku } \\
\text { COVID-19 } \\
\text { COVID-19 test }\end{array}$ & $\begin{array}{l}\text { RT-PCR }(+) \\
\operatorname{PMR}(+)\end{array}$ & $\begin{array}{l}\text { PMR (+) } \\
\text { miesiąc przed } \\
\text { hospitalizacją: test } \\
\text { serologiczny (+) } \\
\text { w trakcie } \\
\text { hospitalizacji: RT- } \\
\text { PCR (+) }\end{array}$ & test serologiczny $(+)$ & $\begin{array}{l}\text { wymaz wykonany } \\
2 \text { tygodnie przed } \\
\text { hospitalizacją }(+) \\
\text { przy przyjęciu: test } \\
\text { serologiczny IgG }(+)\end{array}$ & RT-PCR (+) & RT-PCR $(+)$ \\
\hline
\end{tabular}

Skróty zastosowane w tabeli V: ${ }^{*}$ MCA - middle cerebral artery - tętnica środkowa mózgu, ${ }^{* *} \mathrm{ACA}$ - anterior cerebral artery - tętnica przednia mózgu, ${ }^{* *}$ PCA - posterior cerebral artery - tętnica tylna mózgu, ${ }^{* * *}$ ICA - internal carotid artery - tętnica szyjna wewnętrzna, ${ }^{* * * * *}$ MIS-C Multisystem Inflammatory Syndrome in Children - wieloukładowy zespół zapalny u dzieci, ${ }^{* * * * *}$ ARDS - acute respiratory distress syndrome - zespół ostrej niewydolności oddechowej 


\begin{tabular}{|c|c|c|c|c|c|c|}
\hline Beslow L.A. i wsp & Beslow L.A. i wsp & $\begin{array}{l}\text { Beslow L.A. } \\
\text { i wsp }\end{array}$ & $\begin{array}{l}\text { Beslow L.A. } \\
\text { i wsp }\end{array}$ & $\begin{array}{l}\text { Beslow L.A. } \\
\text { i wsp }\end{array}$ & $\begin{array}{l}\text { Beslow L.A. } \\
\text { i wsp }\end{array}$ & $\begin{array}{l}\text { Beslow L.A. } \\
\text { i wsp }\end{array}$ \\
\hline 28 miesięcy & 16 lat & 32 miesiące & 10 lat & 10 lat & 14 lat & 9 lat \\
\hline żeńska & męska & żeńska & męska & męska & męska & męska \\
\hline brak danych & ból głowy & brak danych & brak danych & brak danych & ból głowy & brak danych \\
\hline $\begin{array}{l}\text { udar niedokrwienny } \\
\text { obejmujący jądra } \\
\text { podstawy, zwężenie } \\
\text { lewej MCA }\end{array}$ & $\begin{array}{l}\text { udar niedokrwienny } \\
\text { w obrębie unaczynienia } \\
\text { lewych: MCA i ACA } \\
\text { oraz prawej ACA, } \\
\text { podejrzenie zapalenia } \\
\text { naczyń mózgowych }\end{array}$ & $\begin{array}{l}\text { udar niedokrwie- } \\
\text { nny w obrębie } \\
\text { śródmózgowia }\end{array}$ & $\begin{array}{l}\text { udar } \\
\text { niedokrwie- } \\
\text { nny w obrębie } \\
\text { unaczynie-nia } \\
\text { lewej i prawej } \\
\text { PCA }\end{array}$ & $\begin{array}{l}\text { udar krwotoczny w } \\
\text { obrębie unaczynienia } \\
\text { prawej MCA, obszary } \\
\text { niedokrwienia w } \\
\text { obrębie móżdżku, } \\
\text { zwężenie prawej ICA }\end{array}$ & $\begin{array}{l}\text { udar niedokrwienny } \\
\text { w obrębie } \\
\text { unaczynienia } \\
\text { prawych: MCA i ACA }\end{array}$ & $\begin{array}{l}\text { udar niedokrwienny } \\
\text { w obrębie prawej } \\
\text { zatoki poprzecznej } \\
\text { i prawej zatoki } \\
\text { esowatej }\end{array}$ \\
\hline brak danych & brak danych & brak danych & brak danych & brak danych & brak danych & brak danych \\
\hline brak & gorączka & gorączka & $\begin{array}{l}\text { gorączka, } \\
\text { kaszel, ciężka } \\
\text { niewydol-ność } \\
\text { oddechowa }\end{array}$ & MIS-C, gorączka & $\begin{array}{l}\text { MIS-C, gorączka, } \\
\text { kaszel, ciężka } \\
\text { niewydolność } \\
\text { oddechowa, } \\
\text { biegunka }\end{array}$ & $\begin{array}{l}\text { kaszel, w RTG klatki } \\
\text { piersiowej obraz } \\
\text { mlecznej szyby }\end{array}$ \\
\hline $\begin{array}{l}\text { test serologiczny } \\
(+)\end{array}$ & RT-PCR (+) & $\begin{array}{l}\text { test serologiczny } \\
\text { ( } 6 \text { tygodni po } \\
\text { wystąpieniu } \\
\text { udaru) }(+)\end{array}$ & RT-PCR (+) & $\begin{array}{l}\text { RT-PCR }(+) \text {, test } \\
\text { serologiczny }(+)\end{array}$ & RT-PCR (+) & RT-PCR (+) \\
\hline
\end{tabular}




\begin{tabular}{|c|c|c|c|c|c|c|c|}
\hline 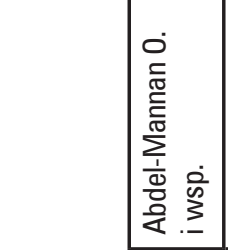 & $\frac{\sqrt{6}}{\frac{10}{2}}$ & 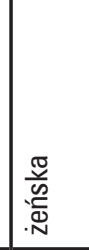 & 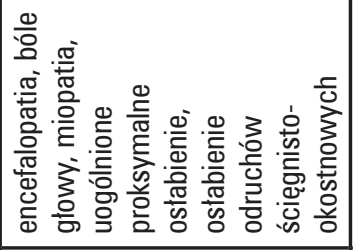 & 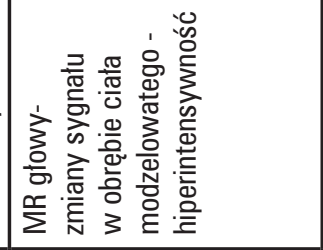 & 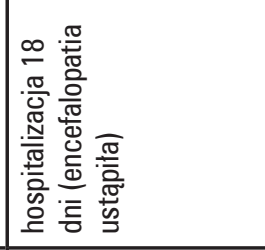 & 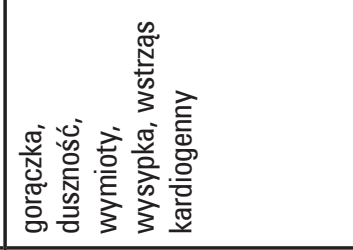 & 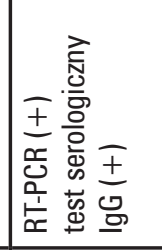 \\
\hline 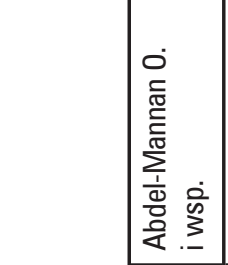 & $\frac{\sqrt{6}}{\frac{\pi}{20}}$ & 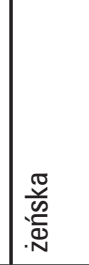 & 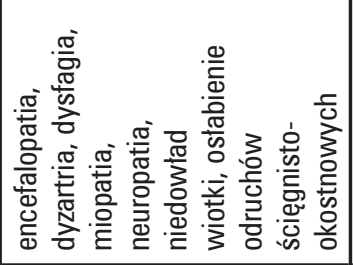 & 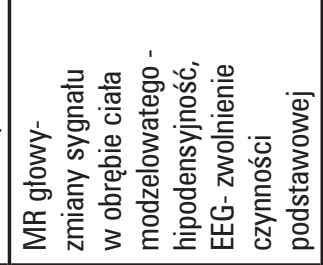 & 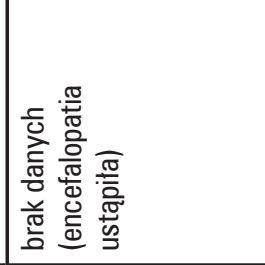 & 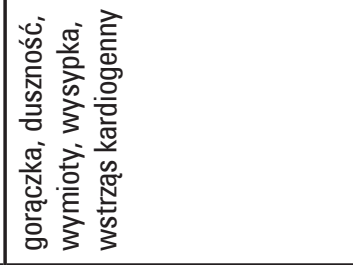 & 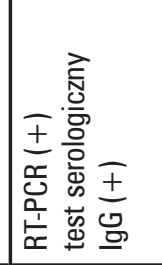 \\
\hline 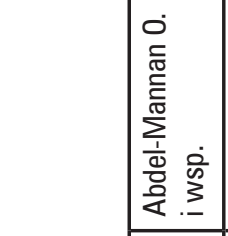 & $\frac{\pi}{\frac{\pi}{2}}$ & \begin{tabular}{|l} 
总 \\
总
\end{tabular} & 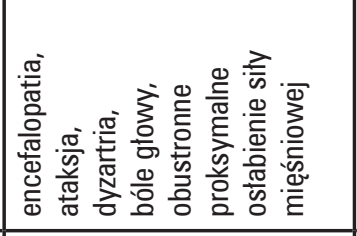 & 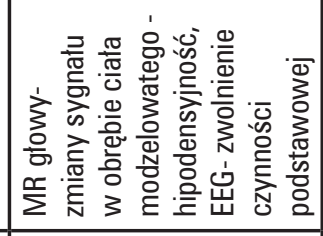 & 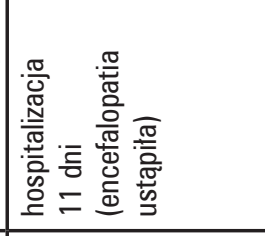 & 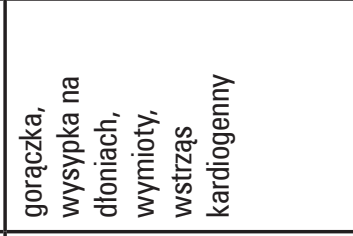 & 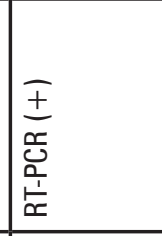 \\
\hline 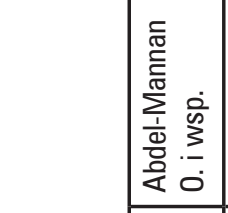 & $\frac{\pi}{\frac{\pi}{\infty}}$ & 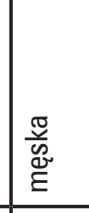 & 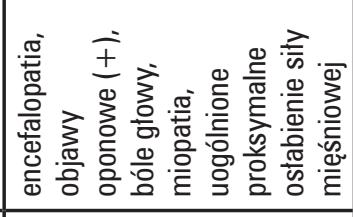 & F & 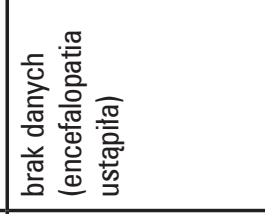 & 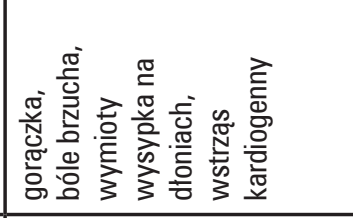 & 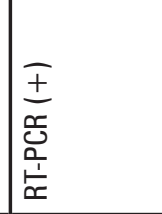 \\
\hline \begin{tabular}{|l}
0 \\
$\frac{0}{3}$ \\
$\frac{3}{0}$ \\
$\frac{0}{\Phi}$ \\
$\frac{0}{<}$ \\
\end{tabular} & 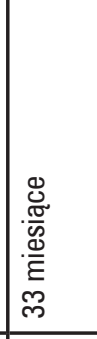 & 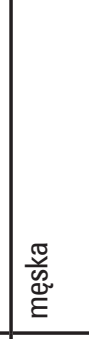 & 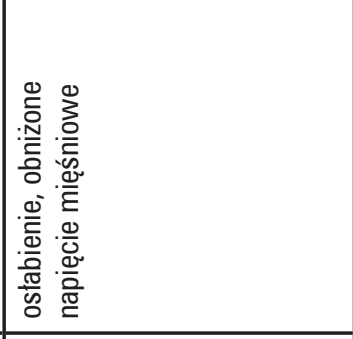 & 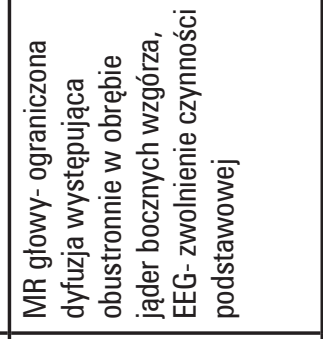 & $\begin{array}{l}\text { 흥 } \\
\text { 오 } \\
\end{array}$ & 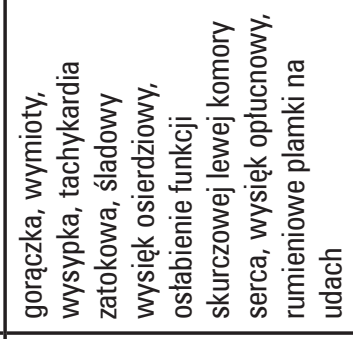 & 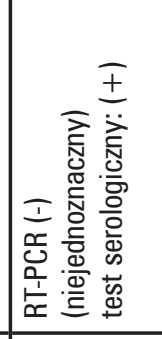 \\
\hline 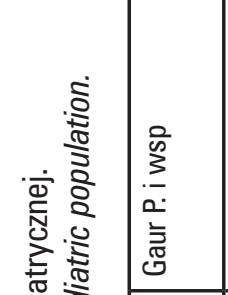 & $\frac{\pi}{\sigma}$ & \begin{tabular}{|l} 
总 \\
恖
\end{tabular} & 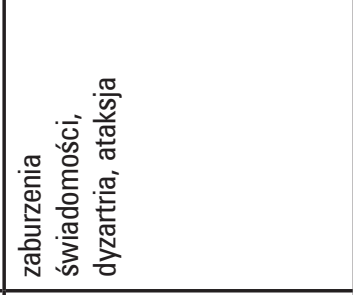 & 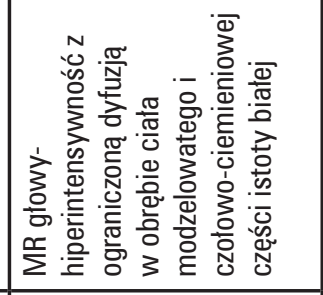 & 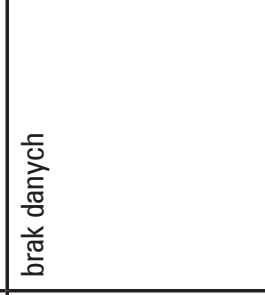 & 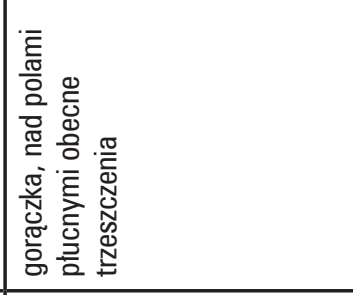 & 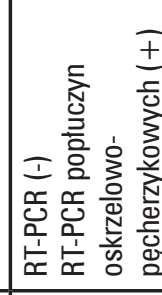 \\
\hline 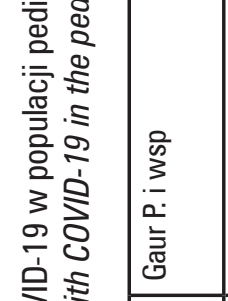 & $\frac{\pi}{\simeq}$ & 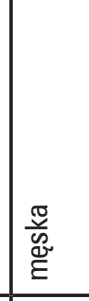 & 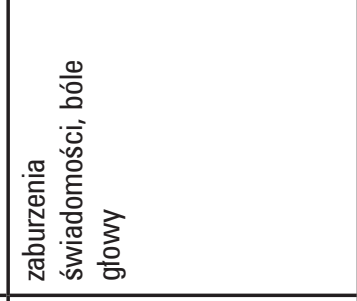 & 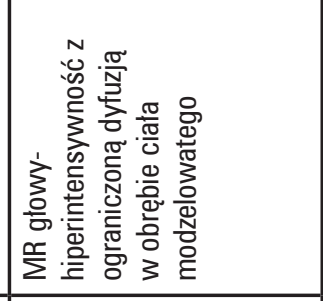 & 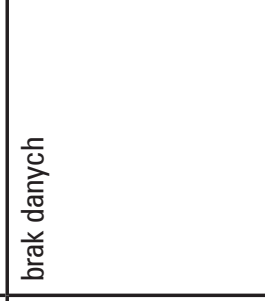 & 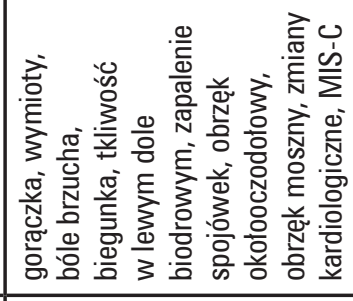 & 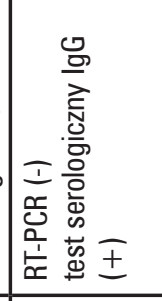 \\
\hline 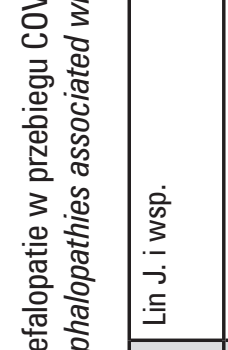 & $\frac{\pi}{\frac{\pi}{m}}$ & 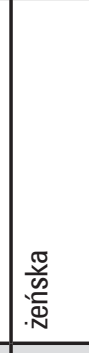 & 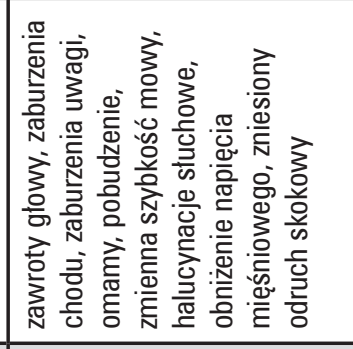 & 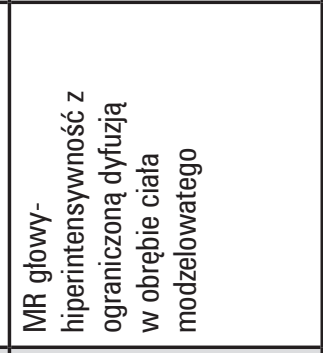 & 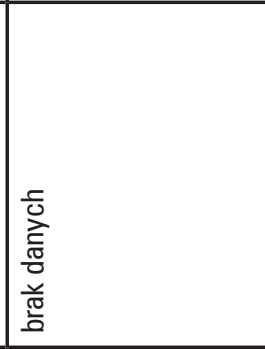 & 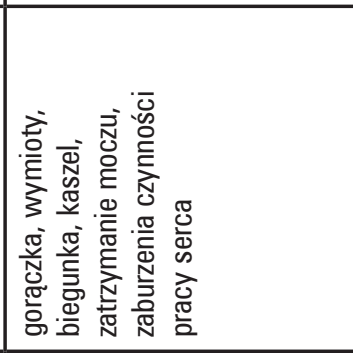 & 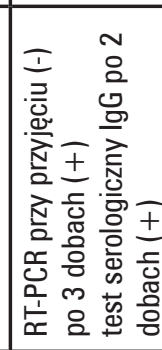 \\
\hline 恶岕 & 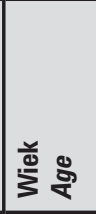 & 党 & 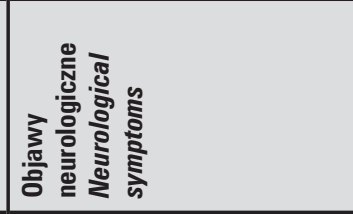 & 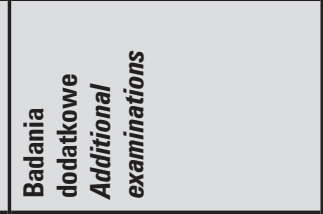 & 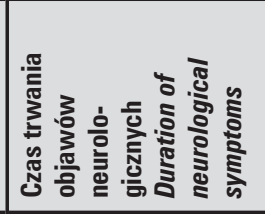 & 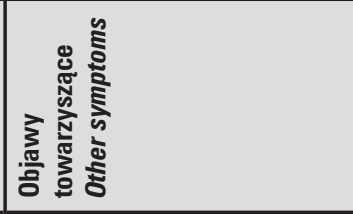 & 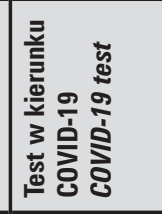 \\
\hline
\end{tabular}




\begin{tabular}{|c|c|c|c|c|c|c|c|c|}
\hline 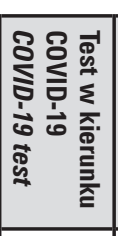 & 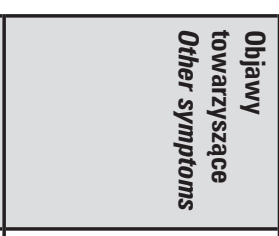 & 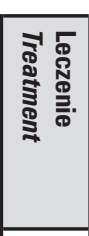 & 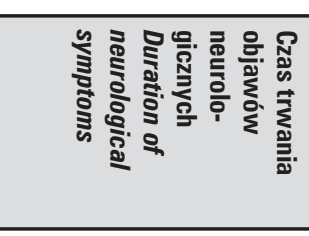 & 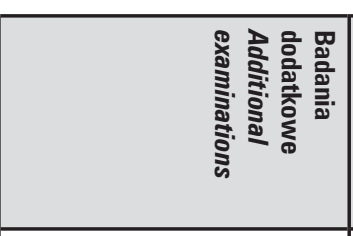 & 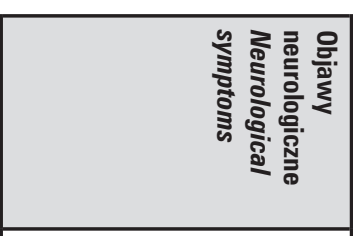 & 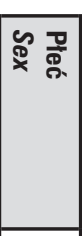 & 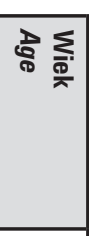 & 旁弯 \\
\hline 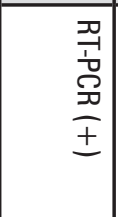 & 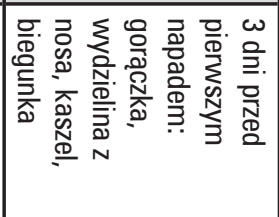 & 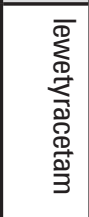 & 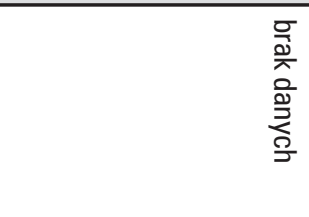 & 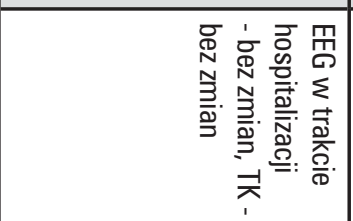 & 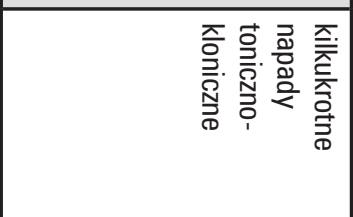 & 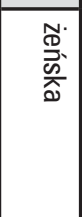 & 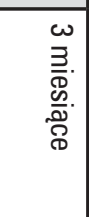 & 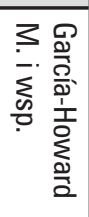 \\
\hline 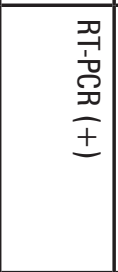 & 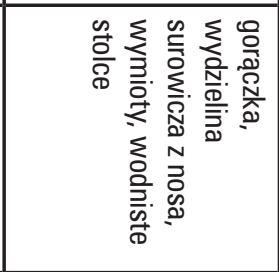 & 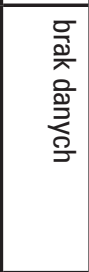 & 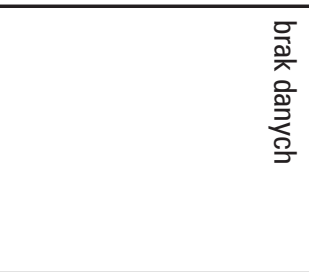 & 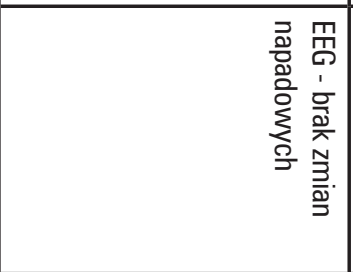 & 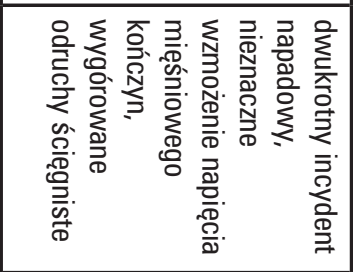 & 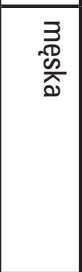 & 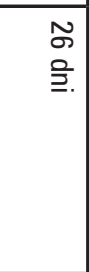 & 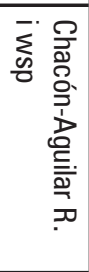 \\
\hline 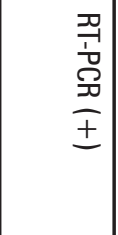 & 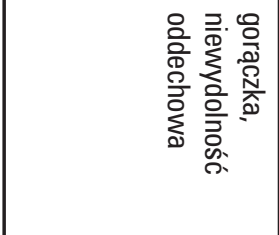 & 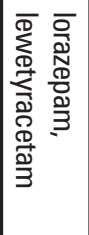 & 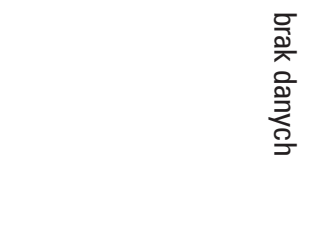 & 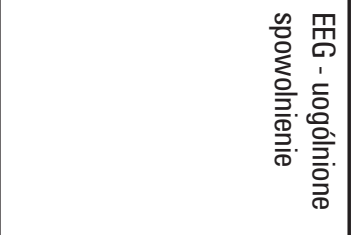 & 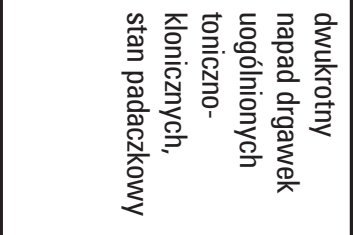 & 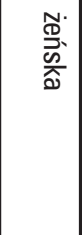 & $\frac{\widetilde{N}}{\stackrel{\widetilde{Q}}{\Phi}}$ & 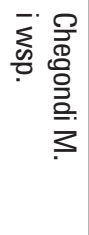 \\
\hline 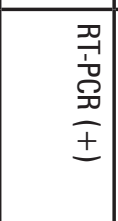 & 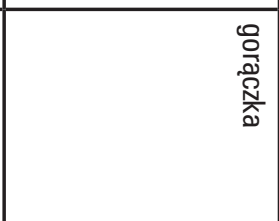 & 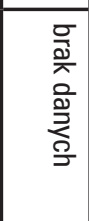 & $\begin{array}{l}\stackrel{p}{\infty} \\
=\end{array}$ & 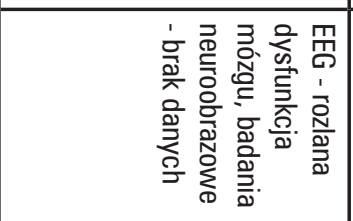 & 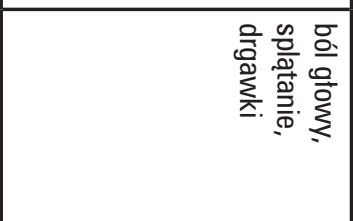 & 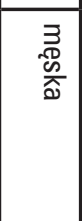 & $\begin{array}{l}\overrightarrow{\vec{N}} \\
\stackrel{\Phi}{N}\end{array}$ & 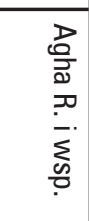 \\
\hline 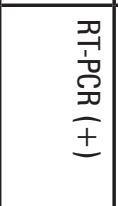 & 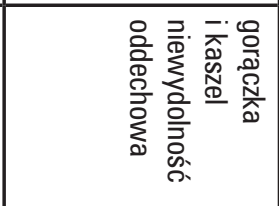 & 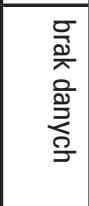 & $\begin{array}{l}\vec{\infty} \\
\varrho \\
\varrho\end{array}$ & 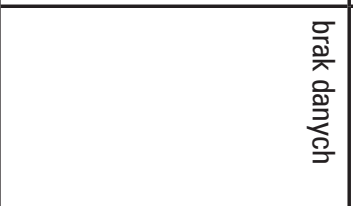 & 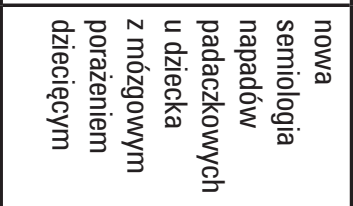 & 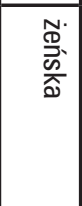 & $\begin{array}{l}\vec{N} \\
\stackrel{N}{N}\end{array}$ & 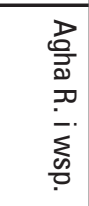 \\
\hline 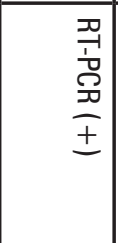 & 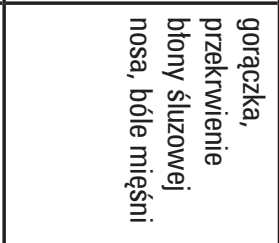 & 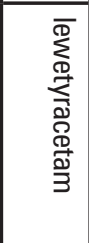 & 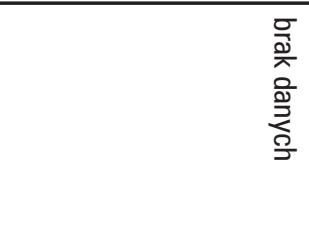 & 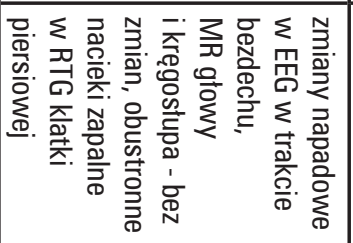 & 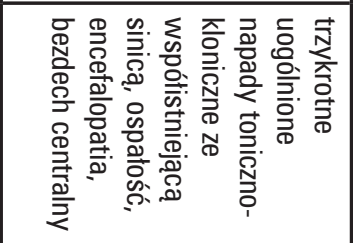 & 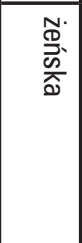 & $\begin{array}{l}\vec{\rightleftarrows} \\
\stackrel{\Phi}{F}\end{array}$ & 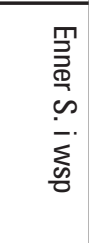 \\
\hline 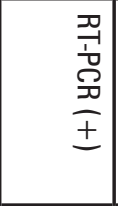 & 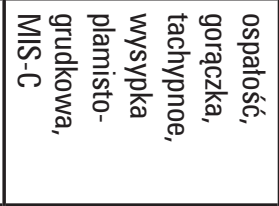 & 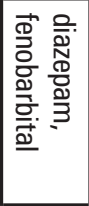 & 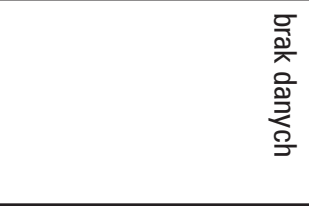 & 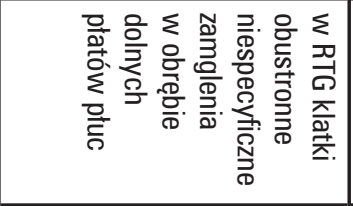 & 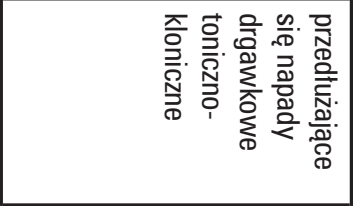 & 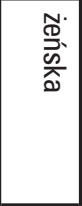 & 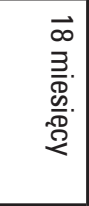 & 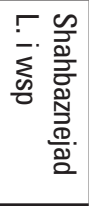 \\
\hline 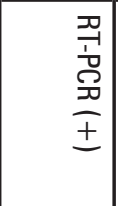 & $\frac{\bar{\sigma}}{\frac{\sigma}{\pi}}$ & 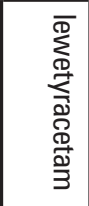 & 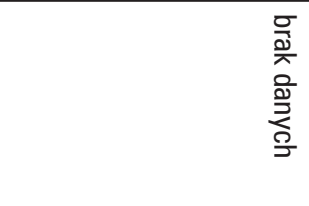 & 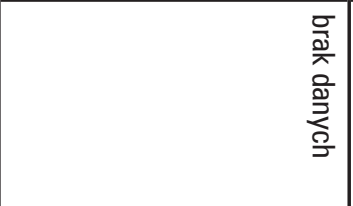 & 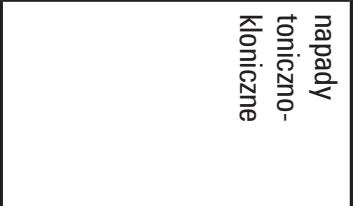 & 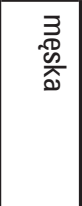 & $\begin{array}{l}\overrightarrow{\bar{ञ}} \\
\stackrel{\Phi}{ }\end{array}$ & 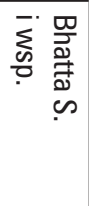 \\
\hline 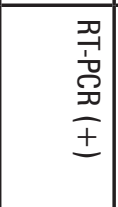 & 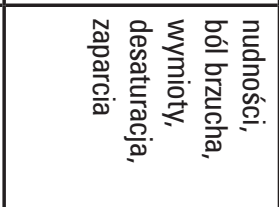 & 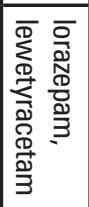 & 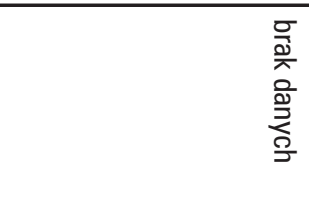 & 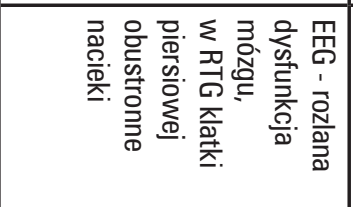 & 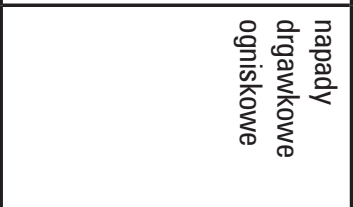 & 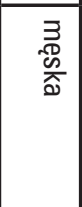 & $\stackrel{\infty}{\Phi}$ & 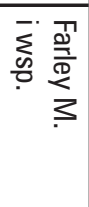 \\
\hline 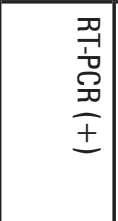 & 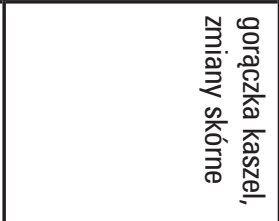 & 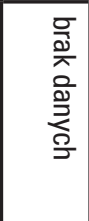 & 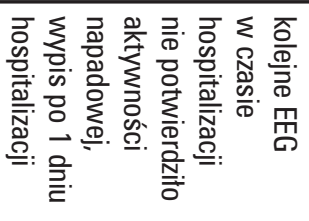 & 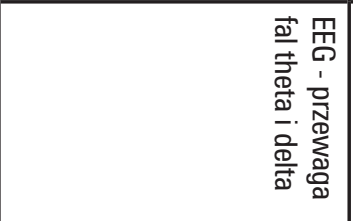 & 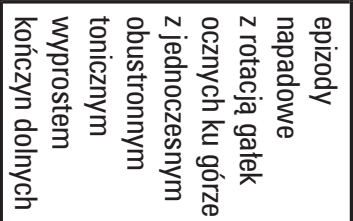 & 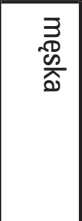 & 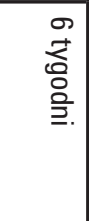 & 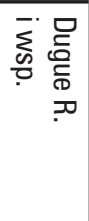 \\
\hline
\end{tabular}


Tabela VIII. Objawy neurologiczne w wieloukładowym zespole zapalnym w populacji pediatrycznej. Table VIII. Neurological symptoms in Multisystem Inflammatory Syndrome in Children

\begin{tabular}{|c|c|c|c|c|}
\hline $\begin{array}{l}\text { Autorzy } \\
\text { Authors }\end{array}$ & Saeed A. i wsp. & $\begin{array}{l}\text { Abdel-Mannan } 0 . \\
\text { i wsp. }\end{array}$ & Abdel-Mannan 0. i wsp. & Abdel-Mannan 0. i wsp. \\
\hline $\begin{array}{l}\text { Wiek (lata) } \\
\text { Age (years) }\end{array}$ & 3 & 8 & 9 & 15 \\
\hline $\begin{array}{l}\text { Płeć } \\
\text { Sex }\end{array}$ & męska & męska & męska & żeńska \\
\hline $\begin{array}{l}\text { Objawy neurologiczne } \\
\text { Neurological symptoms }\end{array}$ & $\begin{array}{l}\text { stereotypie ruchowe } \\
\text { kończyn, następnie } \\
3 \text { napady drgawek } \\
\text { toniczno-klonicznych, } \\
\text { TK głowy - obrzęk } \\
\text { mózgu, } \\
\text { MR głowy - krwotok } \\
\text { śródmózgowy (prawy } \\
\text { płat potyliczny) }\end{array}$ & $\begin{array}{l}\text { encefalopatia, zmiany } \\
\text { sygnału w obrębie } \\
\text { ciała modzelowatego } \\
\text { - hipodensyjność, } \\
\text { spowolnienie w EEG, } \\
\text { objawy oponowe (+), } \\
\text { bóle głowy, miopatia, } \\
\text { uogólnione osłabienie siły } \\
\text { mięśniowej }\end{array}$ & $\begin{array}{l}\text { encefalopatia, zmiany sygnału } \\
\text { w obrębie ciała modzelowatego } \\
\text {-hiperintensywność, spowolnienie } \\
\text { w EEG, ataksja, dyzartria, bóle } \\
\text { głowy, obustronne proksymalne } \\
\text { osłabienie siły mięśniowej kończyn } \\
\text { dolnych }\end{array}$ & $\begin{array}{l}\text { encefalopatia, zmiany sygnału } \\
\text { w obrębie ciała modzelowatego } \\
\text { - hiperintensywność, } \\
\text { zwolnienie czynności } \\
\text { bioelektrycznej w zapisie EEG, } \\
\text { dyzartria, dysfagia, miopatia, } \\
\text { neuropatia, niedowład wiotki }\end{array}$ \\
\hline $\begin{array}{l}\text { Czas trwania objawów } \\
\text { neurologicznych } \\
\text { Duration of neurological } \\
\text { symptoms }\end{array}$ & 8 doba: GCS 15 & $\begin{array}{l}\text { brak danych } \\
\text { (encefalopatia ustąpiła) }\end{array}$ & $\begin{array}{l}\text { hospitalizacja } 11 \text { dni (encefalopatia } \\
\text { ustąpiła) }\end{array}$ & $\begin{array}{l}\text { brak danych } \\
\text { (encefalopatia ustąpiła) }\end{array}$ \\
\hline $\begin{array}{l}\text { Objawy towarzyszące } \\
\text { Other symptoms }\end{array}$ & $\begin{array}{l}\text { gorączka, w TK } \\
\text { klatki piersiowej } \\
\text { charakterystyczne } \\
\text { zmiany dla COVID-19, } \\
\text { hipotensja }\end{array}$ & $\begin{array}{l}\text { gorączka, bóle brzucha, } \\
\text { wymioty, wysypka } \\
\text { na dłoniach, wstrząs } \\
\text { kardiogenny }\end{array}$ & $\begin{array}{l}\text { gorączka, wymioty, wysypka na } \\
\text { dłoniach, wstrząs kardiogenny }\end{array}$ & $\begin{array}{l}\text { gorączka, duszności, wymioty, } \\
\text { wysypka, wstrząs kardiogenny }\end{array}$ \\
\hline $\begin{array}{l}\text { Badania laboratoryjne } \\
\text { Laboratory tests }\end{array}$ & $\begin{array}{l}\text { ferrytyna } 212 \mathrm{ng} / \mathrm{ml} \text {, } \\
\text { prokalcytonina } 4,3 \text {, } \\
\text { CRP } 105 \mathrm{mg} / \mathrm{L} \text {, } \\
\text { troponiny } 79 \mathrm{ng} / \mathrm{ml} \text {, } \\
\text { D-dimery } 3155 \mathrm{ng} / \mathrm{ml} \text {, } \\
\text { kinaza fosfokreatynowa } \\
195 \mathrm{U} / \mathrm{L} \text {, } \\
\text { dehydrogenaza } \\
\text { mleczanowa } \\
900 \mathrm{U} / \mathrm{L}\end{array}$ & $\begin{array}{l}\text { CRP } 44,8 \mathrm{mg} / \mathrm{dl} \text {, } \\
\text { ferrytyna } 1414 \mathrm{ng} / \mathrm{ml} \text {, } \\
\text { D-dimery } 1625,4 \mu \mathrm{g} / \mathrm{ml} \text {, } \\
\text { LDH } 1016 \mathrm{U} / \mathrm{l}\end{array}$ & $\begin{array}{l}\text { CRP } 31,3 \text { mg/dl, ferrytyna } 1192 \mathrm{ng} / \\
\text { ml, D-dimery 494,5 } \mu \mathrm{g} / \mathrm{ml} \text {, LDH } 900 \\
\mathrm{U} / \mathrm{l}, \mathrm{Na} 129 \mathrm{mEq} / \mathrm{L}\end{array}$ & $\begin{array}{l}\text { CRP } 29 \text { mg/dl, ferrytyna } 48142 \\
\mathrm{ng} / \mathrm{ml} \text {, } \\
\text { D-dimery } 1479,8 \mu \mathrm{g} / \mathrm{ml} \text {, LDH } \\
4331 \mathrm{U} / \mathrm{l}\end{array}$ \\
\hline $\begin{array}{l}\text { Test w kierunku COVID-19 } \\
\text { COVID-19 test }\end{array}$ & $\begin{array}{l}\text { RT-PCR: przy przyjęciu } \\
(-) \text {, trzy dni później }(+)\end{array}$ & RT-PCR (+) & RT-PCR (+) & $\begin{array}{l}\text { RT-PCR }(+) \text {, test serologiczny } \\
\operatorname{lgG}(+)\end{array}$ \\
\hline
\end{tabular}

Skróty zastosowane w tabeli VIII: *CRP - C-reactive protein - białko C-reaktywne**PIMS - Paediatric inflammatory multisystem syndrome temporally associated with SARS-CoV-2 - wieloukładowy zespół zapalny u dzieci związany z COVID-19, ***pro-BNP - pro Brain Natriuretic Peptide - mózgowy propeptyd natriuretyczny, ${ }^{* * *}$ INR - international normalized ratio - międzynarodowy wspótczynnik znormalizowany czasu protrombinowego, ${ }^{* * * *}$ APTT - activated partial thromboplastin time - czas częściowej tromboplastyny po aktywacji 


\begin{tabular}{|c|c|c|c|c|c|c|}
\hline $\begin{array}{l}\text { Abdel-Mannan } 0 . \\
\text { i wsp. }\end{array}$ & De Paulis M. i wsp. & Lad S.S. i wsp & Lad S.S. i wsp & Regev T. i wsp. & Lang P. i wsp. & Zombori L. i wsp. \\
\hline 15 & 4 & 7 & 2 & 16 & 13 & 17 \\
\hline żeńska & żeńska & męska & męska & męska & żeńska & żeńska \\
\hline $\begin{array}{l}\text { encefalopatia, } \\
\text { zmiany sygnału } \\
\text { w obrębie ciała } \\
\text { modzelowatego - } \\
\text { hiperintensywność, } \\
\text { bóle głowy, } \\
\text { miopatia, } \\
\text { uogólnione } \\
\text { proksymalne } \\
\text { osłabienie mięśni, } \\
\text { osłabienie } \\
\text { odruchów głębokich }\end{array}$ & $\begin{array}{l}\text { jakościowe } \\
\text { zaburzenia } \\
\text { świadomości - GCS } \\
11\end{array}$ & $\begin{array}{l}\text { drgawki, } \\
\text { encefalopatia, } \\
\text { zmiany w ciele } \\
\text { modzelowatym }\end{array}$ & drgawki & $\begin{array}{l}\text { ból głowy, } \\
\text { sztywność karku, } \\
\text { klonusy }\end{array}$ & $\begin{array}{l}\text { ból głowy, } \\
\text { zaburzenia węchu }\end{array}$ & $\begin{array}{l}\text { zespół Cornelii de Lange } \\
\text { i dobrze kontrolowana } \\
\text { padaczka, MR glowy - } \\
\text { obustronna zmiana sygnału } \\
\text { w obrębie kory mózgu, } \\
\text { móżdżku i wzgórza, } \\
\text { w kontrolnych MRI } \\
\text { głowy: wieloogniskowe } \\
\text { zmiany sygnału, martwica } \\
\text { laminarna w obszarach } \\
\text { wcześniej uszkodzonych, } \\
\text { EEG - rozlana dysfunkcja } \\
\text { mózgu i aktywność } \\
\text { napadowa }\end{array}$ \\
\hline $\begin{array}{l}\text { hospitalizacja } 18 \\
\text { dni (encefalopatia } \\
\text { ustąpita) }\end{array}$ & $\begin{array}{l}\text { w } 17 \text { dobie } \\
\text { zakończenie } \\
\text { hospitalizacji, } \\
\text { w pełni zdrowa }\end{array}$ & brak danych & brak danych & $\begin{array}{l}\text { po } 2 \text { tygodniach } \\
\text { zakończenie } \\
\text { hospitalizacji, } \\
\text { badanie } \\
\text { neurologiczne } \\
\text { w normie poza } \\
\text { uogólnionym } \\
\text { osłabieniem siły } \\
\text { mięśniowej }\end{array}$ & 9 dni & $\begin{array}{l}\text { po } 7 \text { miesiącach chora } \\
\text { z tracheostomią, w trakcie } \\
\text { rehabilitacji, ogólny } \\
\text { stan neurologiczny uległ } \\
\text { pogorszeniu }\end{array}$ \\
\hline $\begin{array}{l}\text { gorączka, } \\
\text { duszności, wymioty, } \\
\text { wysypka, wstrząs } \\
\text { kardiogenny }\end{array}$ & $\begin{array}{l}\text { gorączka, wymioty, } \\
\text { wysypka, obrzęk } \\
\text { powiek, dłoni i } \\
\text { stóp, bóle mięśni, } \\
\text { TK klatki piersiowej } \\
\text { - obraz mlecznej } \\
\text { szyby }\end{array}$ & brak danych & gorączka & $\begin{array}{l}\text { gorączką, } \\
\text { ból brzucha, } \\
\text { zmęczenie, } \\
\text { zapalenie gardła, } \\
\text { nieropne zapalenie } \\
\text { spojówek, rozlana } \\
\text { wysypka plamisto- } \\
\text { grudkowa, } \\
\text { zespół ostrej } \\
\text { niewydolności } \\
\text { oddechowej, } \\
\text { upośledzona } \\
\text { czynność } \\
\text { skurczowa lewej } \\
\text { komory serca, } \\
\text { niedomykalność } \\
\text { zastawki mitralnej }\end{array}$ & $\begin{array}{l}\text { zapalenie wyrostka } \\
\text { robaczkowego ( } 2 \\
\text { tygodnie przed } \\
\text { wystąpieniem } \\
\text { objawów), ból } \\
\text { brzucha, gorączka, } \\
\text { nudności }\end{array}$ & $\begin{array}{l}\text { gorączka kaszel, trudności } \\
\text { w oddychaniu, RTG klatki } \\
\text { piersiowej konsolidacje } \\
\text { w obrębie wnęk, obraz } \\
\text { mlecznej szyby w płucu } \\
\text { lewym; ostre uszkodzenie } \\
\text { nerek, częstoskurcz } \\
\text { komorowy, rabdomioliza, } \\
\text { obustronne zapalenie } \\
\text { rogówki }\end{array}$ \\
\hline $\begin{array}{l}\text { CRP } 32,8 \mathrm{mg} / \mathrm{dl}, \\
\text { ferrytyna } 1218 \mathrm{ng} / \\
\mathrm{ml}, \\
\mathrm{D} \text {-dimery } 1248,6 \\
\mu \mathrm{g} / \mathrm{ml}, \mathrm{LDH} 1168 \mathrm{U} / \mathrm{l}\end{array}$ & $\begin{array}{l}\text { anemia, leukocyty } \\
\text { 30,190/mm3, } \\
\text { neutrofile } 87 \%, \\
\text { trombocyty } 84000 / \\
\mathrm{mm} 3, \text { CRP } 340 \mathrm{mg} / \mathrm{l}, \\
\text { ferrytyna } 582 \mathrm{ng} / \mathrm{ml} \text {, } \\
\text { D-dimery } 5580 \mathrm{ng} / \\
\mathrm{ml} \text {, troponiny } 25,7 \\
\mathrm{pg} / \mathrm{ml}\end{array}$ & brak danych & brak danych & $\begin{array}{l}\text { D-dimery } 3573 \\
\text { ng/ml, troponina I } \\
922 \mathrm{ng} / \mathrm{l}, \mathrm{pro}-\mathrm{BNP} \\
>35,000 \mathrm{pg} / \mathrm{mL} \text {, } \\
\text { CRP } 24 \mathrm{mg} / \mathrm{dl} \text {, } \\
\text { niedokrwistość } \\
\text { normocytarna, } \\
\text { INR } 2.23\end{array}$ & $\begin{array}{l}\text { limfopenia, } \\
\text { trombocytopenia, } \\
\text { podwyższone } \\
\text { stężenie: troponin, } \\
\text { bilirubiny, } \\
\text { D-dimerów }\end{array}$ & $\begin{array}{l}\text { CRP } 345 \mathrm{mg} / \text { l, ferrytyna } \\
2091 \text { ug/l, czas } \\
\text { protrombinowy } 13 \mathrm{~s} \text {, INR } \\
1,3, \text { APTT } 38 \mathrm{~s} \text {, fibrynogen } \\
3,75 \mathrm{~g} / \mathrm{L} \text {, hemoglobina } \\
73 \mathrm{~g} / \mathrm{L} \text {, trombocyty } 51 \times \\
10 \wedge \mathrm{g} / \mathrm{L} \text {, leukocyty } 2.7 \times \\
10 \wedge 9 / \mathrm{L}\end{array}$ \\
\hline $\begin{array}{l}\text { RT-PCR }(+) \text { test } \\
\text { serologiczny } \lg \mathrm{G} \\
(+)\end{array}$ & $\begin{array}{l}\text { test serologiczny } \\
\operatorname{lgG}(+)\end{array}$ & $\begin{array}{l}\text { rozpoznano } \\
\text { PIMS }\end{array}$ & $\begin{array}{l}\text { rozpoznano } \\
\text { PIMS }\end{array}$ & $\begin{array}{l}\text { RT-PCR }(+) \text {, test } \\
\text { serologiczny IgG } \\
(+)\end{array}$ & $\begin{array}{l}\text { RT-PCR }(+) \text {, } \\
\text { test serologiczny } \\
\operatorname{lgG}(+)\end{array}$ & $\begin{array}{l}\text { RT-PCR (+) } \\
\text { (ponadto koinfekcja } \\
\text { Influenza b i P. aeruginosa) }\end{array}$ \\
\hline
\end{tabular}


6 , interleukiny $1 \beta$ i TNF $\alpha$ [61]). Powoduje on naruszenie bariery krew-mózg, nadmierne uwalnianie glutaminianu, interleukiny 6 , interleukiny 12 , interleukiny 15 i TNF- $\alpha$ w OUN $[11,76]$, co prowadzi do rozwoju stanu zapalnego oraz obrzęku mózgu [77]. Ciało modzelowate jest niezwykle podatne na uszkodzenia w tym mechanizmie, gdyż posiada dużą ilość receptorów dla glutaminianu i cytokin, które stymulują powstawanie patologii [76]. W tabeli VII opisano trzy przypadki cytotoksycznego uszkodzenia ciała modzelowatego oraz pięć innych postaci encefalopatii w przebiegu COVID-19 - tabela VII [76-79].

\section{OBJAWY NEUROLOGICZNE W WIELOUKŁADOWYM ZESPOLE ZAPALNYM}

Wieloukładowy zespół zapalny u dzieci związany z COVID-19 (Paediatric inflammatory multisystem syndrome temporally associated with SARS-CoV-2 - PIMS lub Multisystem Inflammatory Syndrome in Children MIS-C) rozwija się 2-4 tygodnie po przechorowaniu COVID-19. W patomechanizmie istotną rolę odgrywa zaburzenie czynności układu odpornościowego [80]. Kryteria diagnostyczne PIMS obejmują [80, 81]:

- wiek $\leq 18 / 19$ lat

- gorączka 3 dni lub dłużej

- objawy towarzyszące pochodzące z minimum 2 narządów/ układów:

- $\quad$ skórno-śluzówkowe: wysypka, zapalenie spojówek, suche i czerwone wargi, obrzęki dłoni i stóp, "truskawkowy język"

- $\quad$ układ krążenia: niedociśnienie, wstrząs, cechy zapalenia mięśnia sercowego, tętniaki tętnic wieńcowych, płyn w osierdziu, zaburzenia rytmu serca

- przewód pokarmowy: biegunka, wymioty, ból brzucha

- $\quad$ układ nerwowy: apatia, drażliwość, ból głowy silny lub o nowym charakterze, niedowłady/porażenia nerwów obwodowych, aseptyczne ZOMR

- układ oddechowy: kaszel, duszność, zapalenie płuc, płyn w opłucnej, ból w klatce piersiowej

- $\quad$ cechy koagulopatii

- podwyższone markery stanu zapalnego: CRP, prokalcytonina, fibrynogen, dehydrogenaza mleczanowa, Ddimery, ferrytyna

- wykluczenie innych przyczyn: ostre zapalenie wyrostka robaczkowego/otrzewnej, choroby układowe tkanki łącznej, choroby rozrostowe, nieswoiste zapalenie jelit, a także przyczyn infekcyjnych i toksycznych obejmujących posocznicę, zespół wstrząsu toksycznego, ostrą chorobę wirusową

- pozytywny wynik testu na COVID-19 metodą RT$\mathrm{PCR} / \mathrm{w}$ teście antygenowym/serologicznym lub prawdopodobny kontakt z osobą COVID-19 (+)

Zespół ten charakteryzuje się dużą różnorodnością objawów, a wśród nich najczęściej zgłaszanymi są gorączka, zaburzenia żołądkowo-jelitowe (80-100\%) oraz zmiany skórne. Objawy neurologiczne występują w około $30 \%$ przypadków [82]. W przypadku podejrzenia PIMS u dziecka należy rozważyć skierowanie pacjenta do szpitala z uwagi na możliwość pogorszenia stanu kliniczne- go. Konieczne jest wykonanie badania potwierdzającego/ wykluczającego zakażenie SARS-CoV-2, a także elektrokardiogramu oraz badania echokardiograficznego serca. Zalecane jest także badanie rentgenowskie klatki piersiowej. W badaniach laboratoryjnych warto zwrócić uwagę na następujące nieprawidłowości towarzyszące PIMS: bardzo wysokie stężenie markerów stanu zapalnego oraz markerów uszkodzenia mięśnia sercowego, limfopenię, niedokrwistość, hipoabuminemię i hiponatremię [80]. W tabeli VIII przedstawiono krótką charakterystykę objawów neurologicznych towarzyszących PIMS [75, 79, 8286]. Niektóre objawy przypominają chorobę Kawasakiego (KD, Kawasaki Disease), jednak pomiędzy tymi dwiema jednostkami chorobowymi występują pewne subtelne różnice. W klasycznej odmianie KD koagulopatia i powikłania ze strony układu pokarmowego występują rzadziej niż w MIS-C. Kolejną cechą różnicującą te dwie choroby jest wiek, w którym występują objawy. Pacjenci poniżej 5 roku życia są bardziej narażeni na KD, z kolei dzieci starsze częściej chorują na MIS-C [87]. Najczęstszymi powikłaniami PIMS są: zapalenia mięśnia sercowego z obniżoną frakcją wyrzutową lewej komory, wstrząs i tętniaki tętnic wieńcowych. Śmiertelność nie jest wysoka i wynosi około 2\% [80]. W badaniu, które obejmowało 187 dzieci, u 34\% $\mathrm{z}$ nich zarejestrowano neurologiczne objawy choroby. Były to głównie bóle głowy oraz objawy meningismus [22]. W badaniach prowadzonych w grupie 99 pacjentów, w tym 53 chłopców, u 13\% dzieci w wieku 0-5 lat oraz u 38\% osób w wieku 13-20 lat zaobserwowano objawy neurologiczne. Również w tym opracowaniu najczęściej pojawiały się bóle głowy [88].

W piśmiennictwie opisano kilkoro dorosłych pacjentów, u których zdiagnozowano analogiczny zespół objawów. Podstawową różnicą było zwiększone nasilenie objawów w stosunku do populacji dziecięcej [89, 90].

\section{WNIOSKI}

Powyższa praca podsumowuje dane z dostępnych dotąd publikacji dotyczących objawów neurologicznych w trakcie zakażenia SARS-CoV-2 w populacji pediatrycznej. W przebiegu COVID-19 występują one relatywnie często. Bóle głowy oraz zaburzenia węchu i smaku są jednymi z głównych manifestacji tej choroby, ale zgodnie $\mathrm{z}$ aktualnym stanem wiedzy, nie niosą za sobą poważnych negatywnych następstw. Ciężkie powikłania neurologiczne, jak na przykład udary niedokrwienne, encefalopatie, zespół Guillaina-Barrego, zapalenie opon mózgowych czy zapalenie mózgu zostały opisane w liczbie kilku/kilkunastu dla każdego z objawów, można więc uznać je za kazuistyczne, biorąc pod uwagę częstość zakażeń SARS-CoV-2 w populacji. Znacząca większość nie pozostawiła po sobie żadnych ubytków neurologicznych. Należy jednak zwrócić uwagę, że chorowały głównie dzieci wcześniej zdrowe, bez chorób towarzyszących i innych obciążeń. Konieczna jest więc dalsza dokładna analiza nowych pojawiających się przypadków zachorowań.

Na szczególną uwagę zasługują chorzy z coraz częściej diagnozowanym PIMS. Ten zespół zapalny niesie ze so- 
bą wiele groźnych powikłań, w tym również neurologicznych. Pojawia się coraz więcej doniesień o negatywnych skutkach PIMS i jego ciężkim przebiegu. Właściwym wydaje się więc uwrażliwienie lekarzy pediatrów, ale również rodziców na objawy mogące sugerować PIMS, aby odpowiednio wcześnie rozpocząć właściwe leczenie.

\section{PIŚMIENNICTWO}

[1] Naqvi A.A.T., Fatima K., Mohammad T. et al.: Insights into SARS-CoV-2 genome, structure, evolution, pathogenesis and therapies: Structural genomics approach. Biochim Biophys Acta Mol Basis Dis 2020; 1866: 165878.

[2] Holshue M.L., DeBolt C., Lindquist S. et al.: First Case of 2019 Novel Coronavirus in the United States. N Engl J Med 2020; 382: 929-936.

[3] Chen Y., Li L.: SARS-CoV-2: virus dynamics and host response. Lancet Infect Dis 2020; 20: 515-516.

[4] Rod J.E., Oviedo-Trespalacios 0., Cortes-Ramirez J.: A brief-review of the risk factors for covid-19 severity. Rev Saude Publica 2020; 54: 60.

[5] Bulut C., Kato Y.: Epidemiology of COVID-19. Turk J Med Sci 2020; 50: 563-570.

[6] Groban L., Wang H., Sun X. et al.: Is Sex a Determinant of CoVID-19 Infection? Truth or Myth? Curr Hypertens Rep 2020; 22: 62.

[7] Comunian S., Dongo D., Milani C. et al.: Air Pollution and Covid-19: The Role of Particulate Matter in the Spread and Increase of Covid-19's Morbidity and Mortality. Int J Environ Res Public Health 2020; 17: 4487.

[8] Webb Hooper M., Nápoles A.M., Pérez-Stable E.J.: COVID-19 and Racial/ Ethnic Disparities. JAMA 2020; 323: 2466-2467.

[9] Moriguchi T., Harii N., Goto J. et al.: A first case of meningitis/encephalitis associated with SARS-Coronavirus-2. Int J Infect Dis 2020; 94: 55-58.

[10] Abdennour L., Zeghal C., Dème M. et al.: Interaction brain-lungs. Ann $\mathrm{Fr}$ Anesth Reanim 2012; 31: 101-107.

[11] Bohmwald K., Gálvez N.M.S., Ríos M. et al.: Neurologic Alterations Due to Respiratory Virus Infections. Front Cell Neurosci 2018; 12: 386.

[12] Unni S.K., Rǔžek D., Chhatbar C. et al.: Japanese encephalitis virus: from genome to infectome. Microbes Infect 2011; 13: 312-321.

[13] Turner A.J., Hiscox J.A., Hooper N.M.: ACE2: from vasopeptidase to SARS virus receptor. Trends Pharmacol Sci 2004; 25: 291-294.

[14] Chen R., Wang K., Yu J. et al: The Spatial and Cell-Type Distribution of SARS-CoV-2 Receptor ACE2 in the Human and Mouse Brains. Front. Neurol. 2021; 11: 573095

[15] Desforges M., Le Coupanec A., Dubeau P. et al.: Human Coronaviruses and Other Respiratory Viruses: Underestimated Opportunistic Pathogens of the Central Nervous System? Viruses 2019; 12: 14

[16] Mori I.: Transolfactory neuroinvasion by viruses threatens the human brain. Acta Virol 2015; 59: 338-349.

[17] Niazkar H.R., Zibaee B., Nasimi A. et al.: The neurological manifestations of COVID-19: a review article. Neurol Sci 2020; 41: 1667-1671.

[18] Lippi G., Mattiuzzi C., Bovo C. et al.: Headache is an important symptom in patients with coronavirus disease 2019 (COVID-19). Diagnosis (Berl) 2020; 7: 409-411.

[19] Garg R.K.: Spectrum of Neurological Manifestations in Covid-19: A Review. Neurol India 2020; 68: 560-572.

[20] Panda P.K., Sharawat I.K., Panda P. et al.: Neurological Complications of SARS-CoV-2 Infection in Children: A Systematic Review and MetaAnalysis. J Trop Pediatr 2020. doi:10.1093/tropej/fmaa070

[21] Stafstrom C.E., Jantzie L.L.: COVID-19: Neurological Considerations in Neonates and Children. Children 2020; 7: 133.

[22] Chen T.H.: Neurological involvement associated with COVID-19 infection in children. J Neurol Sci 2020; 418: 117096.

[23] Jeng M.J.: Coronavirus disease 2019 in children: Current status. J Chin Med Assoc 2020; 83: 527-533.

[24] Khalifa M., Zakaria F., Ragab Y. et al.: Guillain-Barré Syndrome Associated With Severe Acute Respiratory Syndrome Coronavirus 2 Detection and Coronavirus Disease 2019 in a Child. J Pediatric Infect Dis Soc 2020; 9: 510-513.

[25] Hasan I., Saif-Ur-Rahman K., Hayat S. et al.: Guillain-Barré syndrome associated with SARS-CoV-2 infection: A systematic review and individual participant data meta-analysis. J Peripher Nerv Syst 2020; 25: $335-343$.

[26] Rahimi K.: Guillain-Barre syndrome during COVID-19 pandemic: an overview of the reports Neurol Sci 2020; 41: 3149-3156.
[27] Frank C.H.M., Almeida T.V.R., Marques E.A. et al.: Guillain-Barré Syndrome Associated with SARS-CoV-2 Infection in a Pediatric Patient. J Trop Pediatr 2020. doi:10.1093/tropej/fmaa044

[28] Paybast S., Gorji R., Mavandadi S.: Guillain-Barré Syndrome as a Neurological Complication of Novel COVID-19 Infection: A Case Report and Review of the Literature. Neurologist 2020;25:101-103.

[29] Uncini A., Vallat J., Jacobs B.C.: Guillain-Barré syndrome in SARSCoV-2 infection: an instant systematic review of the first six months of pandemic. J Neurol Neurosurg Psychiatry 2020;91:1105-1110.

[30] Cetinkaya E.A.: Coincidence of COVID-19 Infection and Smell-Taste Perception Disorders. J Craniofac Surg 2020; 31: 625-626.

[31] Lima M.A., Silva M.T.T., Oliveira R.V. et al.: Smell dysfunction in COVID-19 patients: More than a yes-no question. J Neurol Sci 2020; 418: 117107.

[32] Sharifian-Dorche M., Huot P., Osherov M. et al.: Neurological complications of coronavirus infection; a comparative review and lessons learned during the COVID-19 pandemic. J Neurol Sci 2020; 417: 117085.

[33] Qiu C., Cui C., Hautefort C. et al.: Olfactory and Gustatory Dysfunction as an Early Identifier of COVID-19 in Adults and Children: An International Multicenter Study. Otolaryngol Head Neck Surg 2020; 163: 714-721.

[34] DeBiasi R.L., Song X., Delaney M. et al.: Severe Coronavirus Disease-2019 in Children and Young Adults in the Washington, DC, Metropolitan Region. J Pediatr 2020; 223: 199-203.

[35] Concheiro-Guisan A., Fiel-Ozores A., Novoa-Carballal R. et al.: Subtle olfactory dysfunction after SARS-CoV-2 virus infection in children. Int $\mathrm{J}$ Pediatr Otorhinolaryngol 2020; 140: 110539.

[36] Mak P.Q., Chung K.S., Wong J.S. et al.: Anosmia and Ageusia: Not an Uncommon Presentation of COVID-19 Infection in Children and Adolescents. Pediatr Infect Dis J 2020; 39: 199-200.

[37] Maniaci A., lannella G., Vicini C. et al.: A Case of COVID-19 with LateOnset Rash and Transient Loss of Taste and Smell in a 15-Year-Old Boy. Am J Case Rep 2020; 21: 925813-1-925813-6.

[38] Hatipoglu N., Yazici Z.M., Palabiyik F. et al.: Olfactory bulb magnetic resonance imaging in SARS-CoV-2-induced anosmia in pediatric cases. Int J Pediatr Otorhinolaryngol 2020; 139: 110469.

[39] Marhaeni W., Wijaya A.B., Kusumaningtyas P. et al.: Thalassemic Child Presenting with Anosmia due to COVID-19. Indian J Pediatr 2020; 87: 750.

[40] Kasuga Y., Nishimura K., Go H. et al.: Severe olfactory and gustatory dysfunctions in a Japanese pediatric patient with coronavirus disease (COVID-19). J Infect Chemother 2021; 27: 110-112.

[41] Ferraro S., Tuccori M., Convertino I. et al.: Olfactory and gustatory impairments in COVID-19 patients: Role in early diagnosis and interferences by concomitant drugs. $\mathrm{Br} \mathrm{J}$ Clin Pharmacol 2020. doi:10.1111/bcp.14634

[42] Podemski R.: Kompendium neurologii. VIA Medica, Gdańsk 2014

[43] Oualha M., Bendavid M., Berteloot L.,et al.: Severe and fatal forms of COVID-19 in children. Arch Pediatr 2020; 27: 235-238.

[44] Kest H., Kaushik A., DeBruin W. et al.: Multisystem Inflammatory Syndrome in Children (MIS-C) Associated with 2019 Novel Coronavirus (SARS-CoV-2) Infection. Case Rep Pediatr 2020; 2020: 8875987.

[45] Freij B.J., Gebara B.M., Tariq R. et al.: Fatal central nervous system coinfection with SARS-CoV-2 and tuberculosis in a healthy child. BMC Pediatr 2020; 20: 429.

[46] Kaur H., Mason J.A., Bajracharya M. et al.: Transverse Myelitis in a Child With COVID-19. Pediatr Neurol 2020; 112: 5-6.

[47] Yousefi K., Poorbarat S., Abasi Z. et al.: Viral meningitis associated with covid-19 in a 9-year-old child: a case report. Pediatr Infect Dis J 2021; 40: 87-98.

[48] Ellul M.A., Benjamin L., Singh B. et al.: Neurological associations of COVID-19. Lancet Neurol 2020; 19: 767-783.

[49] Ye M., Ren Y., Lv T.: Encephalitis as a clinical manifestation of COVID-19. Brain Behav Immun 2020; 88: 945-946.

[50] Conto-Palomino N.M., Cabrera-Bueno M.L., Vargas-Ponce K.G. et al.: Encephalitis associated with COVID-19 in a 13-year-old girl: A case report. Medwave 2020; 20: 7984.

[51] McAbee G.N., Brosgol Y., Pavlakis S. et al.: Encephalitis Associated with COVID-19 Infection in an 11-Year-Old Child. Pediatr Neurol 2020; 109: 94.

[52] de Miranda Henriques-Souza A.M., de Melo A.C.M.G., de Aguiar Coelho Silva Madeiro B. et al.: Acute disseminated encephalomyelitis in a COVID-19 pediatric patient. Neuroradiology 2020; $1-5$.

[53] Qi X., Keith K.A., Huang J.H.: COVID-19 and stroke: A review. Brain Hemorrhages 2020. doi:10.1016/j.hest.2020.11.001

[54] Fullerton H.J., Elkind M.S., Barkovich A.J. et al.: The vascular effects of infection in Pediatric Stroke (VIPS) Study. J Child Neurol 2011; 26: $1101-1110$ 
[55] Mirzaee S.M.M., Gonçalves F.G., Mohammadifard M. et al.: Focal Cerebra Arteriopathy in a Pediatric Patient with COVID-19. Radiology 2020; 297: 274-275

[56] Gulko E., Overby P., Ali S. et al.: Vessel Wall Enhancement and Focal Cerebral Arteriopathy in a Pediatric Patient with Acute Infarct and COVID-19 Infection. AJNR Am J Neuroradiol 2020; 41: 2348-2350.

[57] Kihira S., Morgenstern P.F., Raynes H. et al.: Fatal cerebral infarct in a child with COVID-19. Pediatr Radiol 2020; 50: 1479-1480.

[58] Dakay K., Cooper J., Bloomfield J. et al.: Cerebral Venous Sinus Thrombosis in COVID-19 Infection: A Case Series and Review of The Literature. J Stroke Cerebrovasc Dis 2021;30.

[59] Savić D., Alsheikh T.M., Alhaj A.K. et al.: Ruptured cerebral pseudoaneurysm in an adolescent as an early onset of COVID-19 infection: case report. Acta Neurochir 2020; 162: 2725-2729.

[60] Beslow L.A., Linds A.B., Fox C.K. et al.: Pediatric Ischemic Stroke: An Infrequent Complication of SARS-CoV-2. Ann Neurol 2020. doi:10.1002/ ana.25991

[61] Muhammad S., Petridis A., Cornelius JF. et al..: Letter to editor: Severe brain haemorrhage and concomitant COVID-19 Infection: A neurovascular complication of COVID-19. Brain Behav Immun. 2020; 87: 150-151.

[62] Leung A.K., Hon K.L., Leung T.N.: Febrile seizures: an overview. Drugs Context 2018; 7: 212536.

[63] Laino D., Mencaroni E., Esposito S.: Management of Pediatric Febrile Seizures. Int J Environ Res Public Health 2018; 15: 2232.

[64] García-Howard M., Herranz-Aguirre M., Moreno-Galarraga L. et al.: Case Report: Benign Infantile Seizures Temporally Associated With COVID-19. Front Pediatr 2020; 8: 507.

[65] Chacón-Aguilar R., Osorio-Cámara J.M., Sanjurjo-Jimenez I. et al.: COVID-19: Fever syndrome and neurological symptoms in a neonate. An Pediatr 2020; 92: 373-374.

[66] Chegondi M., Kothari H., Chacham S. et al.: Coronavirus Disease 2019 (COVID-19) Associated With Febrile Status Epilepticus in a Child. Cureus 2020; 12: 9840.

[67] Agha R., Kojaoghlanian T., Avner J.R.: Initial Observations of COVID-19 in US Children. Hosp Pediatr 2020; 10: 902-905.

[68] Enner S., Hormozdyaran S., Varughese R. et al.: Central Apnea in an Adolescent With COVID-19. Pediatr Neurol 2020; 110: 87-88.

[69] Shahbaznejad L., Navaeifar M.R., Abbaskhanian A. et al.: Clinical characteristics of 10 children with a pediatric inflammatory multisystem syndrome associated with COVID-19 in Iran. BMC Pediatr 2020; 20: 513

[70] Bhatta S., Sayed A., Ranabhat B. et al.: New-Onset Seizure as the Only Presentation in a Child With COVID-19. Cureus 2020; 12: 8820.

[71] Farley M., Zuberi J.: COVID-19 Precipitating Status Epilepticus in a Pediatric Patient. Am J Case Rep 2020; 21: e925776.

[72] Dugue R., Cay-Martínez K.C., Thakur K.T. et al.: Neurologic manifestations in an infant with COVID-19. Neurology 2020; 94: 1100-1102.

[73] Garazzino S., Montagnani C., Donà D. et al.: Multicentre Italian study of SARS-CoV-2 infection in children and adolescents. Euro Surveill 2020; 25: 2000600 .

[74] Granata T., Bisulli F., Arzimanoglou A. et al.: Did the COVID-19 pandemic silence the needs of people with epilepsy? Epileptic Disord 2020; 22: 439-442.

[75] Saeed A., Shorafa E.: Status epilepticus as a first presentation of COVID-19 infection in a 3 years old boy. Case report and review the literature. IDCases 2020; 22: 00942.
[76] Lin J., Lawson E.C., Verma S. et al.: Cytotoxic Lesion of the Corpus Callosum in an Adolescent with Multisystem Inflammatory Syndrome and SARSCoV-2 Infection. AJNR Am J Neuroradiol 2020;41: 2017-2019.

[77] Gaur P., Dixon L., Jones B. et al.: COVID-19-Associated Cytotoxic Lesions of the Corpus Callosum. AJNR Am J Neuroradiol 2020; 41: 1905-1907.

[78] Abel D., Shen M.Y., Abid Z. et al: Encephalopathy and bilateral thalamic lesions in a child with MIS-C associated with COVID-19. Neurology 2020; 95: 745-748.

[79] Abdel-Mannan 0., Eyre M., Löbel U. et al.: Neurologic and Radiographic Findings Associated With COVID-19 Infection in Children. JAMA Neurol 2020; 77: 1-6.

[80] Okarska-Napierała M., Ludwikowska K., Książyk J. et al.: Postępowanie z dzieckiem z wieloukładowym zespołem zapalnym powiązanym z COVID-19. Przegl Pediatr 2020; 49:1-9.

[81] Elias M.D., McCrindle B.W., Larios G. et al.: Management of Multisystem Inflammatory Syndrome in Children Associated With COVID-19: A Survey From the International Kawasaki Disease Registry. CJC Open 2020; 2: 632-640.

[82] De Paulis M., Oliveira D.B.L., Vieira R.P. et al.: Multisystem Inflammatory Syndrome Associated With COVID-19 With Neurologic Manifestations in a Child: A Brief Report. Pediatr Infect Dis J 2020; 39: 321-324.

[83] Lad S.S., Kait S.P., Suryawanshi P.B. et al.: Neurological Manifestations in Pediatric Inflammatory Multisystem Syndrome Temporally Associated with SARS-CoV-2 (PIMS-TS). Indian J Pediatr 2020; 1-2.

[84] Regev T., Antebi M., Eytan D. et al.: Pediatric Inflammatory Multisystem Syndrome With Central Nervous System Involvement and Hypocomplementemia Following SARS-COV-2 Infection. Pediatr Infect Dis J 2020; 39: 206-207.

[85] Lang P., Eichholz T., Bakchoul T. et al.: Defibrotide for the Treatment of Pediatric Inflammatory Multisystem Syndrome Temporally Associated With Severe Acute Respiratory Syndrome Coronavirus 2 Infection in 2 Pediatric Patients. J Pediatric Infect Dis Soc 2020; 9: 622-625.

[86] Zombori L., Bacon M., Wood H. et al.: Severe cortical damage associated with COVID-19 case report. Seizure 2021; 84: 66-68.

[87] Kabeerdoss J., Pilania R.K., Karkhele R. et al.: Severe COVID-19, multisystem inflammatory syndrome in children, and Kawasaki disease: immunological mechanisms, clinical manifestations and management. Rheumatol Int 2021; 41: 19-32.

[88] Dufort E.M., Koumans E.H., Chow E.J. et al.: Multisystem Inflammatory Syndrome in Children in New York State. N Engl J Med 2020; 383: 347 358.

[89] Morris S.B., Schwartz N.G., Patel P. et al.: Case Series of Multisystem Inflammatory Syndrome in Adults Associated with SARS-CoV-2 Infection - United Kingdom and United States, March-August 2020. MMWR Morb Mortal Wkly Rep 2020; 69: 1450-1456.

[90] Pouletty M., Borocco C., Ouldali N. et al.: Paediatric multisystem inflammatory syndrome temporally associated with SARS-CoV-2 mimicking Kawasaki disease (Kawa-COVID-19): a multicentre cohort. Ann Rheum Dis 2020; 79: 999-1006.

Adres do korespondencji: Justyna Paprocka, Katedra i Klinika Neurologii Dziecięcej, Wydział Nauk Medycznych w Katowicach, Śląski Uniwersytet Medyczny, Katowice, justyna.paprocka@interia.pl 